\title{
Article \\ Chemical and Isotopic Tracers for Characterization of the Groundwater in the Heterogeneous System: Case from Chichaoua-Imin'tanout (Morocco)
}

\author{
Rim Tijani ${ }^{1, *}$, Abdennebi El Mandour ${ }^{1}$, Driss Chafouq ${ }^{1}$, Malak Elmeknassi ${ }^{1} \mathbb{D}$, Fatima Ezzahra El Ghazali ${ }^{1} \mathbb{D}$ \\ and Lhoussaine Bouchaou 2,3 \\ 1 GeoSciences Semlalia Laboratory, Faculty of Sciences Semlalia, Cadi Ayyad University, \\ Marrakesh 40000, Morocco; aelmandour@uca.ac.ma (A.E.M.); dchafouq@gmail.com (D.C.); \\ malak.elmeknassi@gmail.com (M.E.); elghazali.fz@gmail.com (F.E.E.G.) \\ 2 Laboratory of Applied Geology and Geo-Environment, Ibn Zohr University, Agadir 80035, Morocco; \\ Ibouchaou@gmail.com \\ 3 International Water Research Institute, Mohammed VI Polytechnic University, Ben Guerir 43150, Morocco \\ * Correspondence: rim.tijani@ced.uca.ma
}

Citation: Tijani, R.; El Mandour, A.; Chafouq, D.; Elmeknassi, M.; El

Ghazali, F.E.; Bouchaou, L. Chemical and Isotopic Tracers for

Characterization of the Groundwater in the Heterogeneous System: Case from Chichaoua-Imin'tanout (Morocco). Water 2022, 14, 9. https://doi.org/10.3390/ w14010009

Academic Editor: Domenico Cicchella

Received: 31 October 2021

Accepted: 9 December 2021

Published: 21 December 2021

Publisher's Note: MDPI stays neutral with regard to jurisdictional claims in published maps and institutional affiliations.

Copyright: (c) 2021 by the authors. Licensee MDPI, Basel, Switzerland. This article is an open access article distributed under the terms and conditions of the Creative Commons Attribution (CC BY) license (https:// creativecommons.org/licenses/by/ $4.0 /)$.

\begin{abstract}
The geological and hydrogeological approach of the structure of the basin OuladBouSbaâ led to the definition of the geometry of the main aquifers. In general, the profiles show the complexity of the geological configuration. The filling of the depression of OuladBouSbaa is from the EoCretacian. At this level, the aquifer is recharged by direct water infiltration. The quaternary, Eocene, and Cenomanian-Turonian formations constitute the main aquifers. Horizontal as well as vertical heterogeneity lead to a higher diversification of aquifer characteristics. To define the origins and understand the groundwater flows in this complex zone, we used a multi-tracer approach with the analysis of major elements and the isotopes of $\delta^{2} \mathrm{H}$ and $\delta^{18} \mathrm{O}$. The chemical composition is mainly governed by the interaction with the rock with low electrical conductivity except in areas around domestic landfills. Geochemical results analyzing groundwater in the Piper diagram show two distinct chemical facies: the sulfated calcium and magnesium, and the hyper-chloride calcium. The levels of $\delta^{18} \mathrm{O}$ range from -7.60 to -4.25 while those of $\delta^{2} \mathrm{H}$ vary between -53.07 and -27.03 . Analyses of signature isotopes differentiate two groups. The first contains high levels of heavy isotopes (highest levels of $\delta^{2} \mathrm{H}$ and $\delta^{18} \mathrm{O}$ ) having therefore been submitted to evaporation. The second with lower levels of $\delta^{2} \mathrm{H}$ and $\delta^{18} \mathrm{O}$ did not undergo evaporation. The first one belongs to the unconfined free aquifer while the second corresponds to the captive aquifer.
\end{abstract}

Keywords: central Morocco; groundwater; piezometry; geochemistry; isotopes stable

\section{Introduction}

Groundwater is almost the only available resource to satisfy water needs for drinking and irrigation in semi-arid areas such as Morocco and other Mediterranean countries [1]. However, the quality as well as the quantity of this valuable resource in these areas are increasingly threatened by human and natural processes such as salinization, pollution, and climate change [2-11]. This can hamper social development, especially in areas where agriculture is still the main activity of the population. The agricultural sector can be significantly affected by the increasing contamination of groundwater by chemicals that can limit crop growth and change soil properties such as permeability [12-16].

Groundwater salinization was related to natural processes such as climate change [17], the interaction of water and geological layers [18-23], seawater intrusion [24-30], the ascent of fossil saline waters from deep layers [31], and the contamination by saline waters [32-34]. Man-made activities (septic tank effluent, synthetic fertilizer use) can also amplify the effect through intensive irrigation, reduction in the quality and usage of groundwater, and the development of landfills [35-39]. 
Groundwater pollution issues are of serious concern nowadays [40]. Increased rates of nitrates, found in drinking water, are considered a health hazard since they may lead to methemoglobinemia in human infants, a life-threatening syndrome involving impaired oxygen transport in the blood.

Geochemistry of the aquifers can explain some factors such as prior geological conditions and current anthropic activities that affect groundwater quality [41]. However, the local and regional importance of the aquifers, the main hydrogeological governing models, and the origin of groundwater remains poorly understood [42]. Hydro-chemistry and isotope marking have been used to approach the effect of these multiple factors on the origin of the mineralization as well as its evolution [8,43]. The multi-tracer approach, using isotopes and solute concentrations in water, was used to establish the origin and the interaction between different aquifers [44-48].

In addition, this multidisciplinary approach can lead to efficient exploitation of the groundwater systems [49-51], such as establishing new boreholes for agricultural and drinking water supply [52].

The Ouled BouSbaâ basin is home to around 212,778 inhabitants mainly working in agriculture and herding, and occasionally artisanal crafts such as tapestry. The aquifers in this area are overexploited because they are the only resource for the increasing needs of drinking water and irrigation.

The main objective of this study is to analyze the hydrogeological basin of Ouled BouSbaa in central Morocco using a multidisciplinary approach including geology, piezometers, hydro-chemical, and isotope evaluation. We will define the number and nature of the hydro-geological structures, the extension of the aquifer system, and explore the effect of salinization, pollution, and the different modes of water supply in the different aquifers.

Our area is in the form of a set of superimposed and juxtaposed reservoirs. It is very complex and that is what makes studying in this region very difficult. Across the western limit of Ouled Bousbaa formed by the Haouz plain which is a subsidizing basin, contains many isotopic studies $\left({ }^{18} \mathrm{O}\right.$ and $\left.{ }^{2} \mathrm{H}\right)$ which show that the water table is fed at the level of the High Atlas [53]. Its results are identical to the results found by the deepwater table of Ouled Bousbaa.

The main issue of our study is nitrate contamination in the line. They are very high in places, and this is due firstly to the diffuse pollution of nitrates used in agriculture, secondly to the discharge of untreated wastewater from urban areas and unsealed landfills, and thirdly to phosphate deposits in the formations of the Eocene. The drinking water supply is provided by boreholes carried out by the National Office of Electricity and Drinking Water showing low nitrate values. This makes the risk of human contamination low.

The main objective remains to develop a water management model for efficient and sustainable use of surface and groundwater in this basin.

\section{Geographical and Geological Context}

The area under investigation of $6560 \mathrm{~km}^{2}$ is part of the 'Hydraulic Basin Agency of Tensift wadi in the center-west of Morocco. The basin is delimited by the western High Atlas Mountains to the South-West, Tensift wadi to the North, Chichaoua wadi to the East, and the Meskala-Korimate basin to the West. The main localities of the investigated area are Chichoua in the North-East, Sidi El Mokhtar in the North, Taftacht North-West, Imin'Tanout in the South, and Bouabout in the Southern-West part.

The Ouled BouSbaa basin (Figure 1) is located in the Western Meseta of Morocco. The regional geology shows that the deposits started in the Primary (Cambrian) up to the Quaternary (Holocene). The Primary layers outcrop in the Southern part of the area. They are mainly composed of shales, sandstone shales, clay shales, and conglomerates of the Cambro-Permian. 


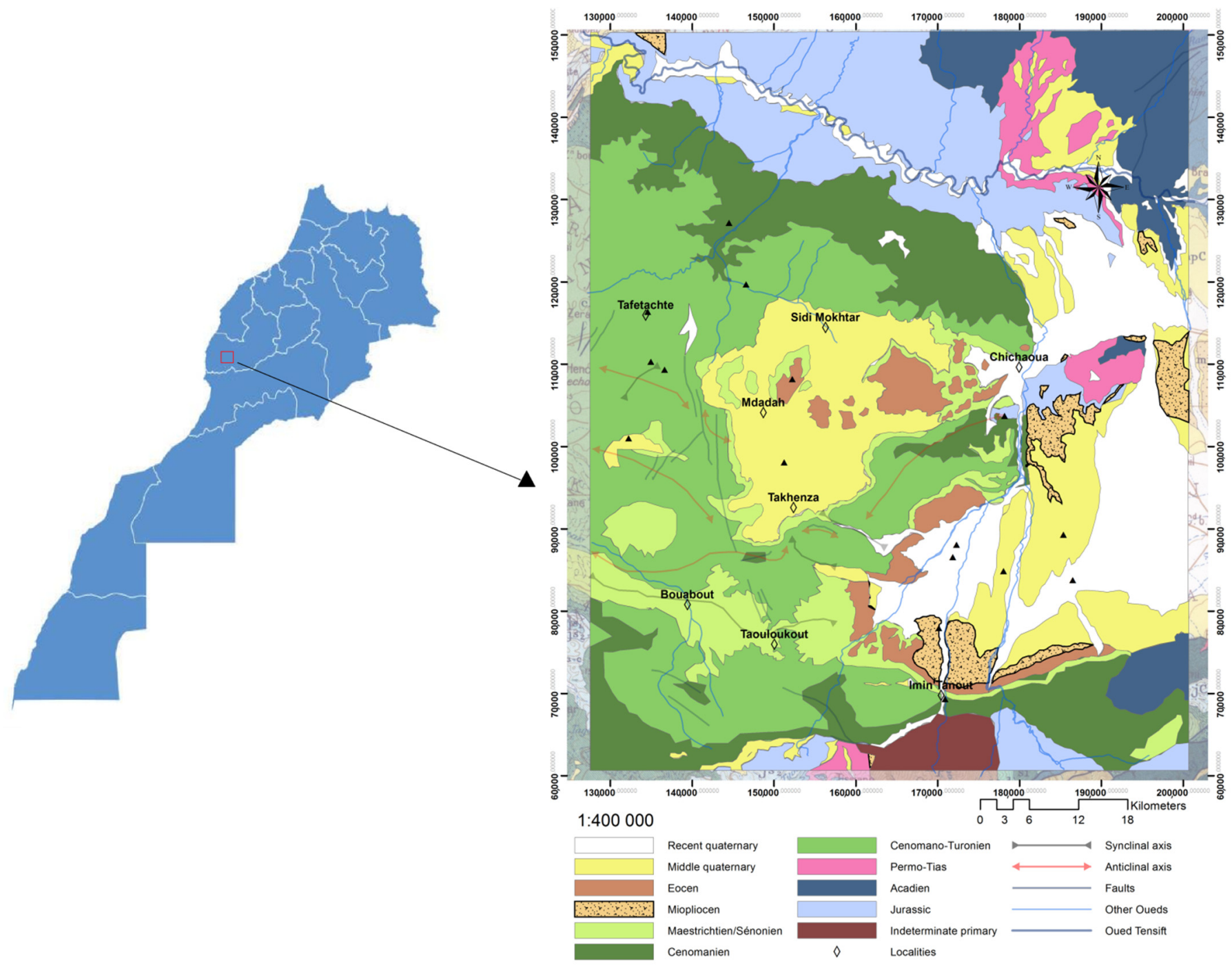

Figure 1. Geographical location and Geology of OuledBouSbaâ basin (according to the 1:50,000 geological map of Morocco).

The synthetic stratigraphic log (Figure 2) shows the different geological formations in the investigated area. In general, the thickness of the different geological layers varies from a zone to another one. According to many authors [54-58], all the geological formations of the Quaternary-Tertiary can reach up to $600 \mathrm{~m}$ thickness while those of the Cretaceous reach $1800 \mathrm{~m}$. Figure 2 below gives the thickness of the different layers and the main lithological facies. Four geological profiles were developed from the drilling logs, geological maps, and field observations (Figure 3).

- $\quad$ Profiles 1 and 2 describe two synclines and one anticline separated by Cretaceous layers under Lower Cretaceous formations (Sidi Mokhtar). The first cuvette of Sidi Mokhtar shows Eocene formations in the surface laying on limestone from CenomanianTuronian. These structures cover green marls and marl limestones of the Lower Cretaceous. The anticline of Marmouta favors the occurrence of resurgences of the aquifer (source 497/52). The second cuvette of Douirane is formed by the Quaternary that sits on the Mio-Pliocene and the Cenomanian-Turonian (that comes to the surface toward the west).

- $\quad$ Profile 3 highlights the Sidi Mokhtar Syncline with Mio-Pliocene and Eocene filling over the Cenomanian-Turonian limestone. Cretaceous outcrops around the Sub-Atlas structure as shown in the southern part of the profile. 
Profile 4 displays the part of the High Atlas where the Primary formations become almost vertical, the structures of the Douirane basin (mainly quaternary and Mio-Pliocene), and the anticline of Marmouta.

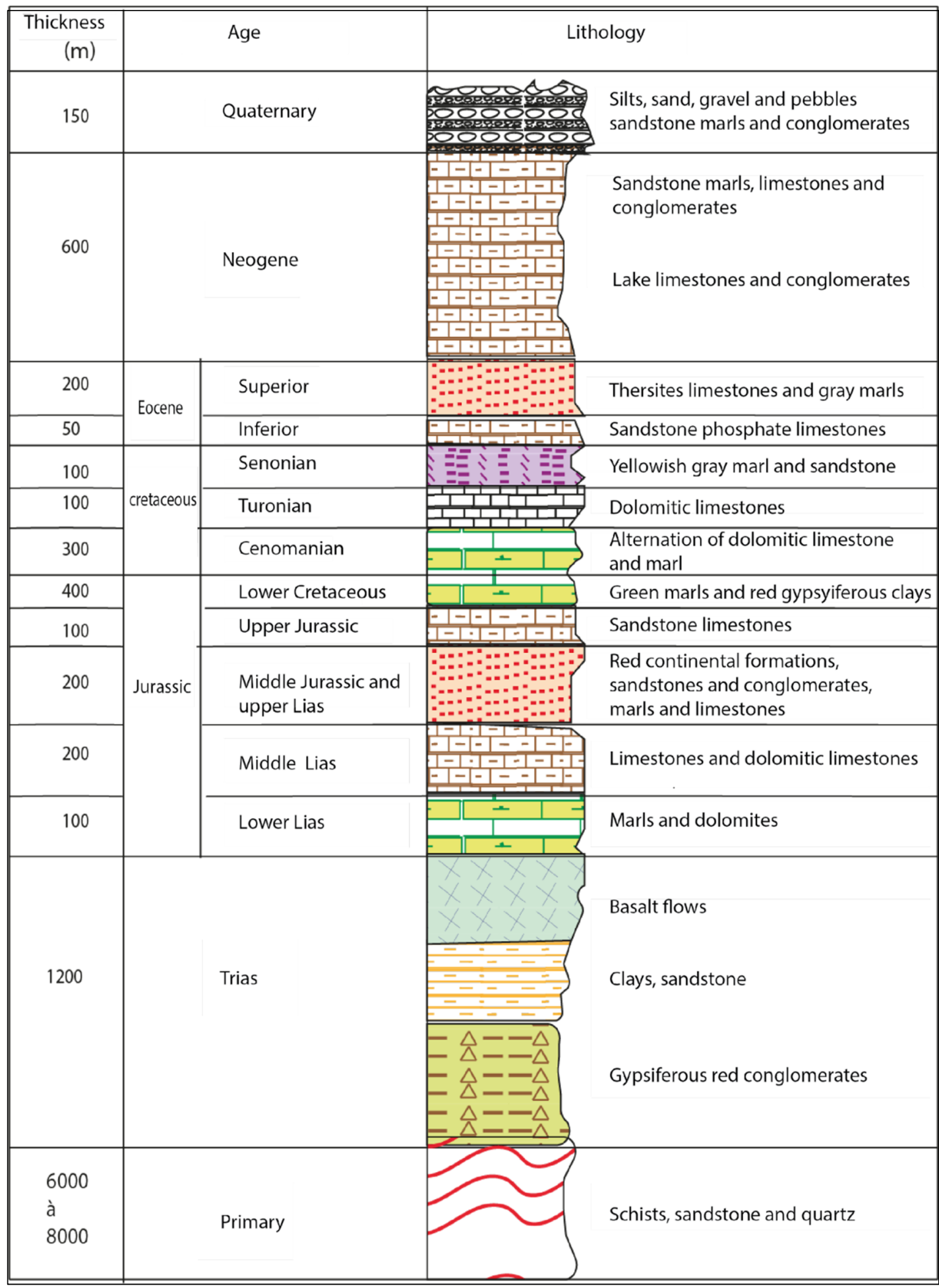

Figure 2. Litho-stratigraphy of western Haouz plain [59]. 

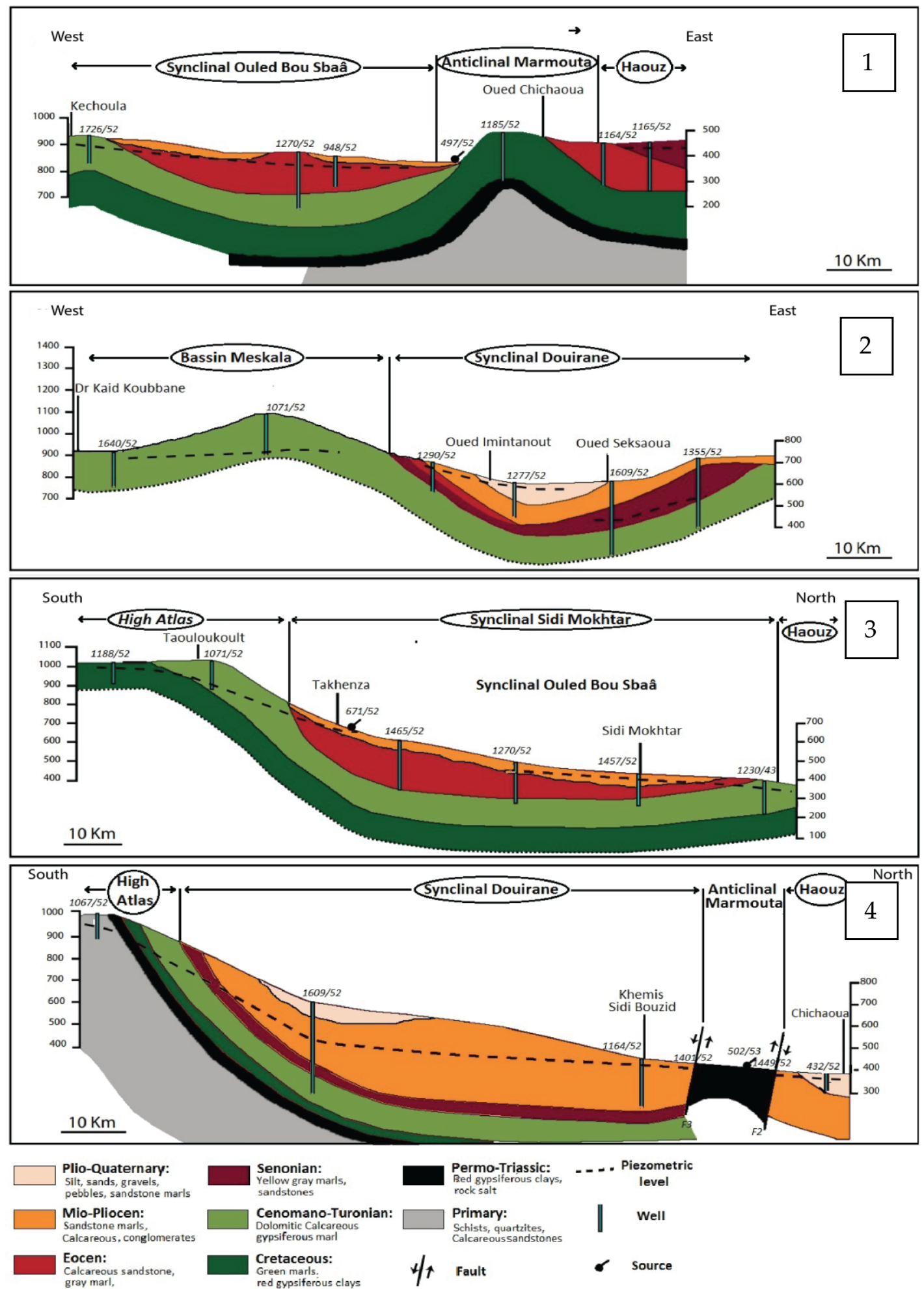

(a)

Figure 3. Cont. 


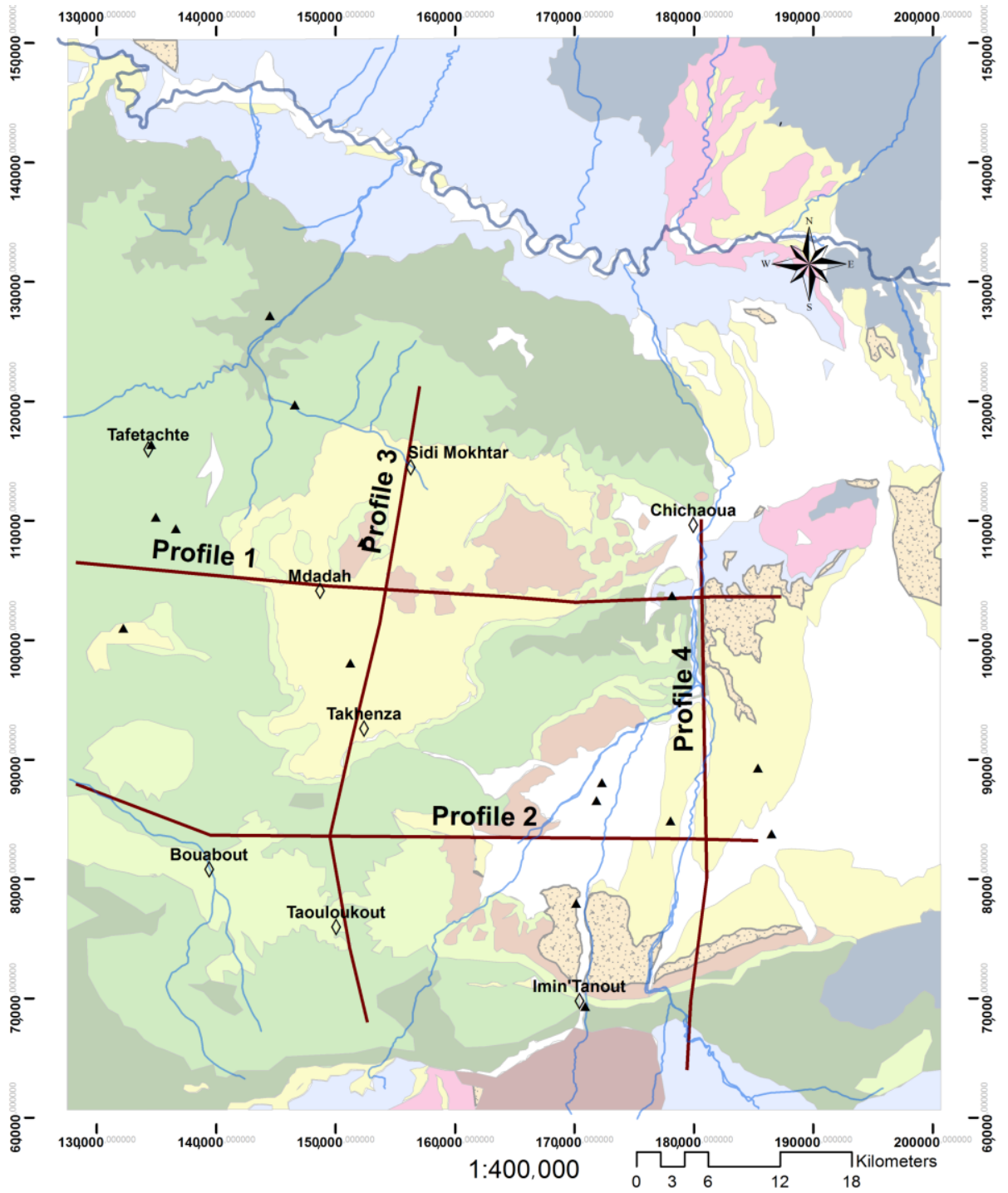

(b)

Figure 3. (a) Geological cross-sections; (b) Location of the profiles.

\section{Climate and Hydrology}

The climate of the area is influenced by its continental localization as well as its proximity to the High Atlas Mountains [60]. Rainfall is generally low characterized by a wide Spatio-temporal variability. The average annual rainfall (Figure $4 \mathrm{~b}$ ) is around $205 \mathrm{~mm}$, ranging from $86 \mathrm{~mm}$ to $386 \mathrm{~mm}$. The rainy season generally extends from October to May (Figure $4 b$ ).

The average temperature is between 15 and $20^{\circ} \mathrm{C}$ with important contrasts in daily, seasonal and annual variations. In general, the climate of the area is arid in the plains and semi-arid in the mountain piedmont, and relatively rainy in the Mountains, which is the main supply for rivers coming from the Atlas.

The average annual evaporation varies between $1800 \mathrm{~mm}$ in the north on the Atlas foothills and $2600 \mathrm{~mm}$ in the center (basin of Sidi Mokhtar) and the south (region of the Tensift river) of the plain. The minimum values are recorded during January, while the maximum values characterize the months of July and August. Almost $60 \%$ of total evaporation is recorded during the four months from June to September. 
The hydrographic system is less dense in the central part. The area is drained in its Eastern zone by Chichaoua wadi (Figure 1). All the drainage network contributes to Tensift River (main collector in the Haouz area) flow during the rainy periods.

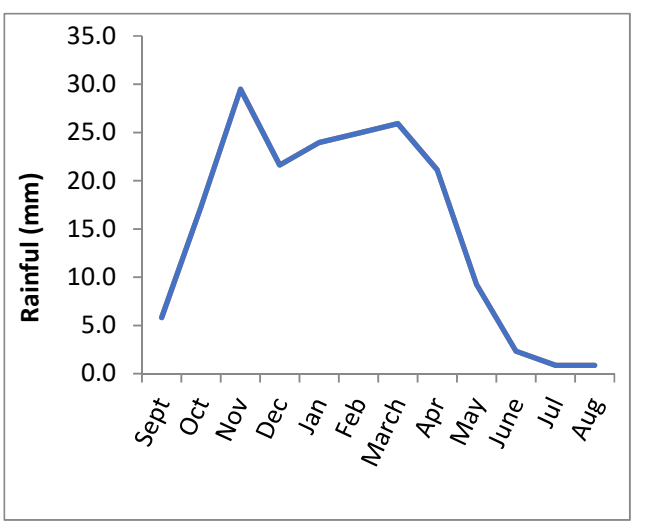

(a)

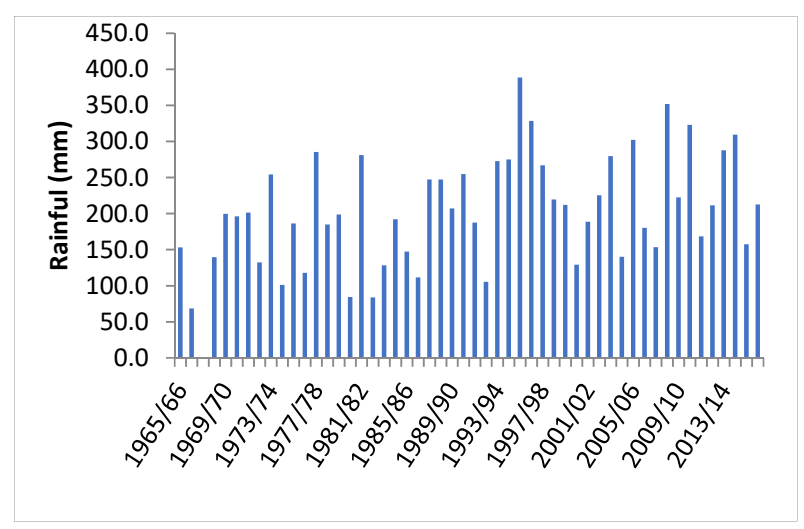

(b)

Figure 4. (a) Average monthly rainfall distribution in the station of Chichaoua (1965-2014); (b) Average annual rainfall distribution in the station of Chichaoua.

The relief of the anticline of Marmouta trending NE-SW between Bouabout and Chichaoua gives two sub-watersheds. The Douirane sub-basin, located to the SE of the plain, is drained by the Chichaoua wadi and its tributaries; Wadi Ameznas in the west, Imintanout in the center, and Sekssaoua in the east. These three wadis Ameznas, Imintanout, and Sekssaoua are often dry; their flow depends on the importance of the rainy episodes and the flow of the sources. The northern sub-basin of Ouled BouSbaa (Sidi Mokhtar basin) is drained by the Mramer wadi and its tributaries Bourgua and Fagh and the Matil wadi in the Bouabout area.

The hydrographic network plays an important role in its «underflows». The transversal plains with their low altitude are the outlets for the excess water of each sub-basin. The streams that perpendicularly cross the geological formations can have a draining effect.

\section{Hydrogeology}

Three main aquifers could be identified in the Ouled Bousbaâ basin based on the results of geology, structure, and geophysics, along with the inventory of water sources and borehole logs. They are aquifers of the Quaternary, Turonian, and Vraconian (belonging to lower Cretaceous) representing complex aquifer profiles with unequal sizes.

The water table of white limestone of the Quaternary is limited by green marls of the Coniacian: it is separated into two parts by the Marmouta anticline. The first represents the syncline of Sidi Mokhtar, and the second called cuvette of Douirane. The thickness of the aquifer is variable but increases from the riverside towards the center of the plain.

The deep aquifer of Turonian limestone, limited by Cenomanian grey marls, spreads out to almost all the basins except in areas of the anticline structures where Vraconian and Cenomanian formations crop out (Figure 3(a1,2)). The thickness of this aquifer varies from $20 \mathrm{~m}$ in the cuvette of Sidi Mokhrtar to $200 \mathrm{~m}$ towards the East and South. In the Douirane sector, the thickness is greater than $140 \mathrm{~m}$ in the central south area (Figure 3(a3,4)).

The deep aquifer of Vraconian limestone limited by the green marls of the Aptian covers almost all the basin except in the anticline zones. The height of the Vraconian wall ranges from 850 to $1400 \mathrm{~m}$ to sea level. In the northern sector, the map shows the extension limit of the Vraconian towards the Northeast and North area along with an important asymmetrical depression that outcrops in the southern area. In the southern sector, there is a wide depression corresponding to a structure oriented SW-NE [61-64].

The transmissivity has been raised during pumping tests carried out by the Haouz hydraulic basin agency. For the free water table, these values vary from $1.1 \times 10^{-5}$ to 
$6.5 \times 10^{-2}$, while for the captive aquifer the values are between $4 \times 10^{-5}$ to $5.6 \times 10^{-2}$. This reflects the good productivity of the two reservoirs.

Indeed, the two aquifers are homogeneous and isotropic.

This work will report mainly on the quaternary and Turonian aquifers, the deep Vraconian aquifer is represented only by two sample sites.

Piezometry

The hydrological system of the study area showed the existence of impermeable as well as permeable series that can allow interstitial or fissured groundwater flow. Groundwater circulation is mainly longitudinal but can be transversal in anticlinal relays and faults [58-67].

The depth of groundwater varies from 22 to $240 \mathrm{~m}$ under the soil level. Nevertheless, the exceptional depth of $508 \mathrm{~m}$ was the only borehole capturing water from the Vraconian. The shallow groundwater was observed close to the surface water streams while the deepest were observed in the frontal zone. The lowest elevation of groundwater was $325 \mathrm{~m}$ close to the Tensift wadi in the North-western zone, while the highest reached $740 \mathrm{~m}$ in the South close to Imintanout at the High Atlas piedmont.

\section{Methodology}

A sampling campaign was carried out in May 2017 in the whole area. The Electrical Conductivity, $\mathrm{pH}$, and temperature of the groundwater were directly measured in the field. Water samples were collected in $1 \mathrm{~L}$ polyethylene bottles, thoroughly washed and rinsed to avoid any contamination. The bottles were transported at $4{ }^{\circ} \mathrm{C}$ and kept at this temperature in the lab. The sampling points were chosen to be distributed over the different parts of the area depending on the aquifer captured.

A total of 46 samples (including 27 capturing the phreatic aquifers and 18 capturing the captive aquifer) were analyzed for the major anions (Chloride, Nitrate, and Sulfate) and cations (Calcium, Magnesium, Potassium, and Sodium). Volumetric methods were used for $\mathrm{HCO}, \mathrm{Ca}, \mathrm{Mg}$, and $\mathrm{Cl}$ dosage in the Laboratory of Applied Geology and Geo-Environment (LAGAGE); Ibn Zohr University.

A flame photometer was used to measure $\mathrm{Na}$ and $\mathrm{K}$ and a spectrophotometer for $\mathrm{SO}_{4}$.

Analyses of ${ }^{2} \mathrm{H}$ and ${ }^{18} \mathrm{O}$ were carried out on 30 samples collected and stored as recommended by [65].

The $\delta^{2} \mathrm{H}$ and $\delta^{18} \mathrm{O}$ of groundwater were obtained by $\mathrm{H}_{2}$ and $\mathrm{CO}_{2}$ equilibrium, respectively, using Isotope Ratio Mass Spectrometry (IRMS) on a delta S Finnigan Mat in the Laboratory of Applied Geology and Geo-Environment (LAGAGE); Ibn Zohr University.

The isotope ratios are expressed in terms of $\delta \%$ relative to V-SMOW (Vienna Standard Ocean Mean Water). The ratios were calculated using International and Internal standards. Simple reproducibility was within $\pm 0.5 \%$ for $\delta^{2} \mathrm{H}$ and $\pm 0.2 \%$ for $\delta^{18} \mathrm{OH}_{2} \mathrm{O}$.

Stable isotope ratios were expressed in part per thousand (\%) using the conventional delta notation:

$$
\delta \%=\left[\frac{R_{(\text {sample })}}{R_{(V-S M O W)}}-1\right] * 10^{3}
$$

With $\mathrm{R}$ representing one of the ratios: $18 \mathrm{O} / 16 \mathrm{O}$ and $2 \mathrm{H} / 1 \mathrm{H}$ for the samples (R(Sample)) and the Standards (R(V-SMOW)).

\section{Results: Hydrochemistry Characterization}

The map (Figure 5) shows the scattering of the groundwater sampled points in the study area. Table 1 presents chemical and isotopes data of the sampling campaigns for the investigated aquifers. The data and discussion that follows are presented as a function of geographic distribution in the basin (Figure 5). 


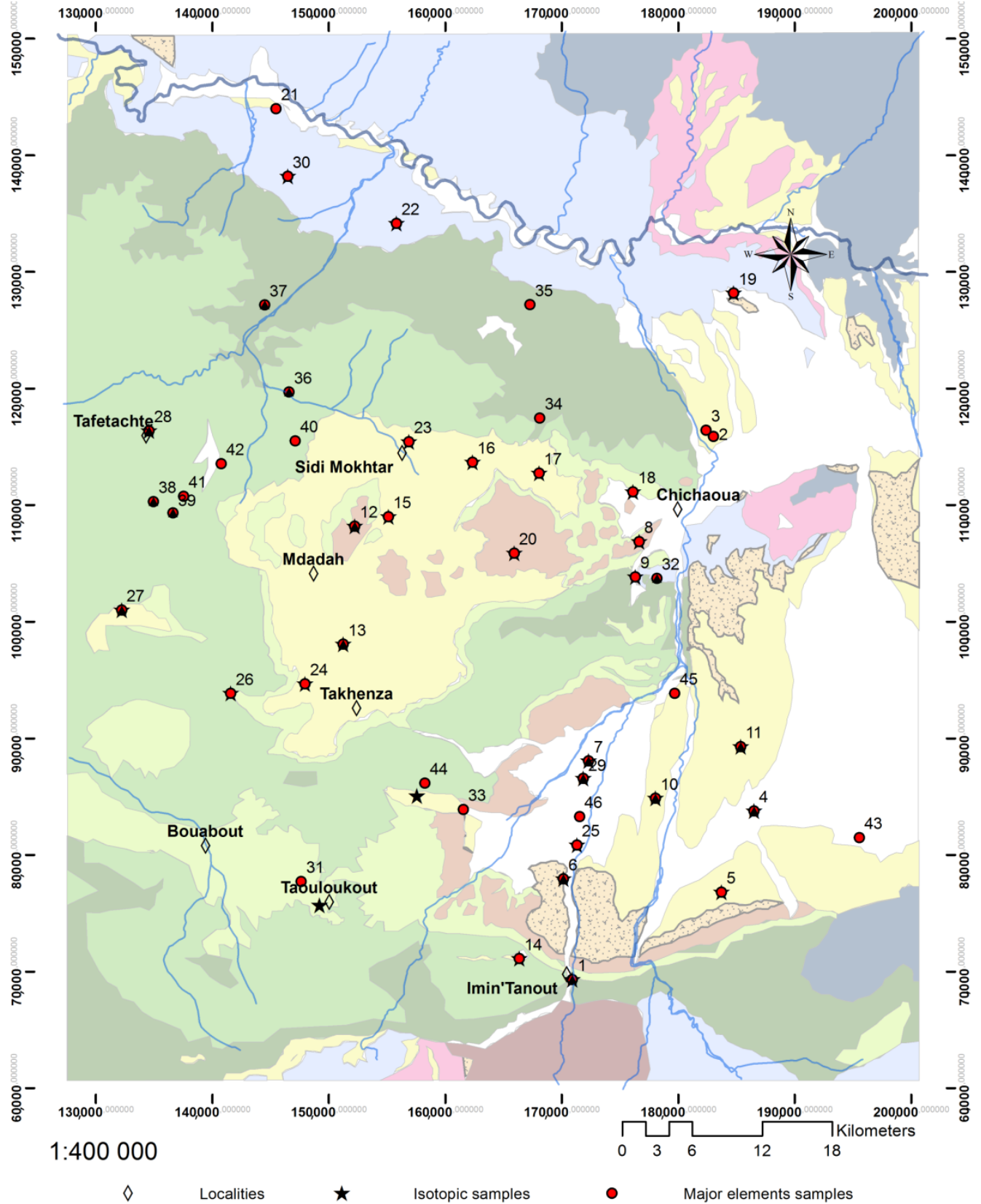

Figure 5. Location of hydrochemical and isotopic samples.

During the sampling campaign of May 2017, the temperature of groundwater samples ranged from $20.4{ }^{\circ} \mathrm{C}$ (well 31) to $27.2{ }^{\circ} \mathrm{C}$ (well 9), with an average of $23.98{ }^{\circ} \mathrm{C}$ (Table 1 ). These values are typical for the hypothermal cold waters reflecting the seasonal changes. The values of $\mathrm{pH}$ varied from 7.1 (well 24) to 8.4 (well 26), indicating the neutral to alkaline nature of groundwater. The Electrical Conductivity (EC) was variable in the zone extending from $228 \mu \mathrm{S} / \mathrm{cm}$ in the South to $3245 \mu \mathrm{S} / \mathrm{cm}$ toward Tensiftwadi which constitutes the main collector of the global area.

\subsection{Spatial Distribution of the Electric Conductivity (EC)}

The objective of the electrical conductivity map (Figure 6) is to investigate the origin and the spatial evolution of groundwater mineralization and the interaction of water with the geological layers. EC values in the free aquifer are ranging between 228 and $3245 \mu \mathrm{S} / \mathrm{cm}$ (Figure 6a). High values were observed downstream from Chichaoua and Imintanout. 
Table 1. Hydrochemical and isotopic values of collected samples from OuleBouSbaa plain, Morocco.

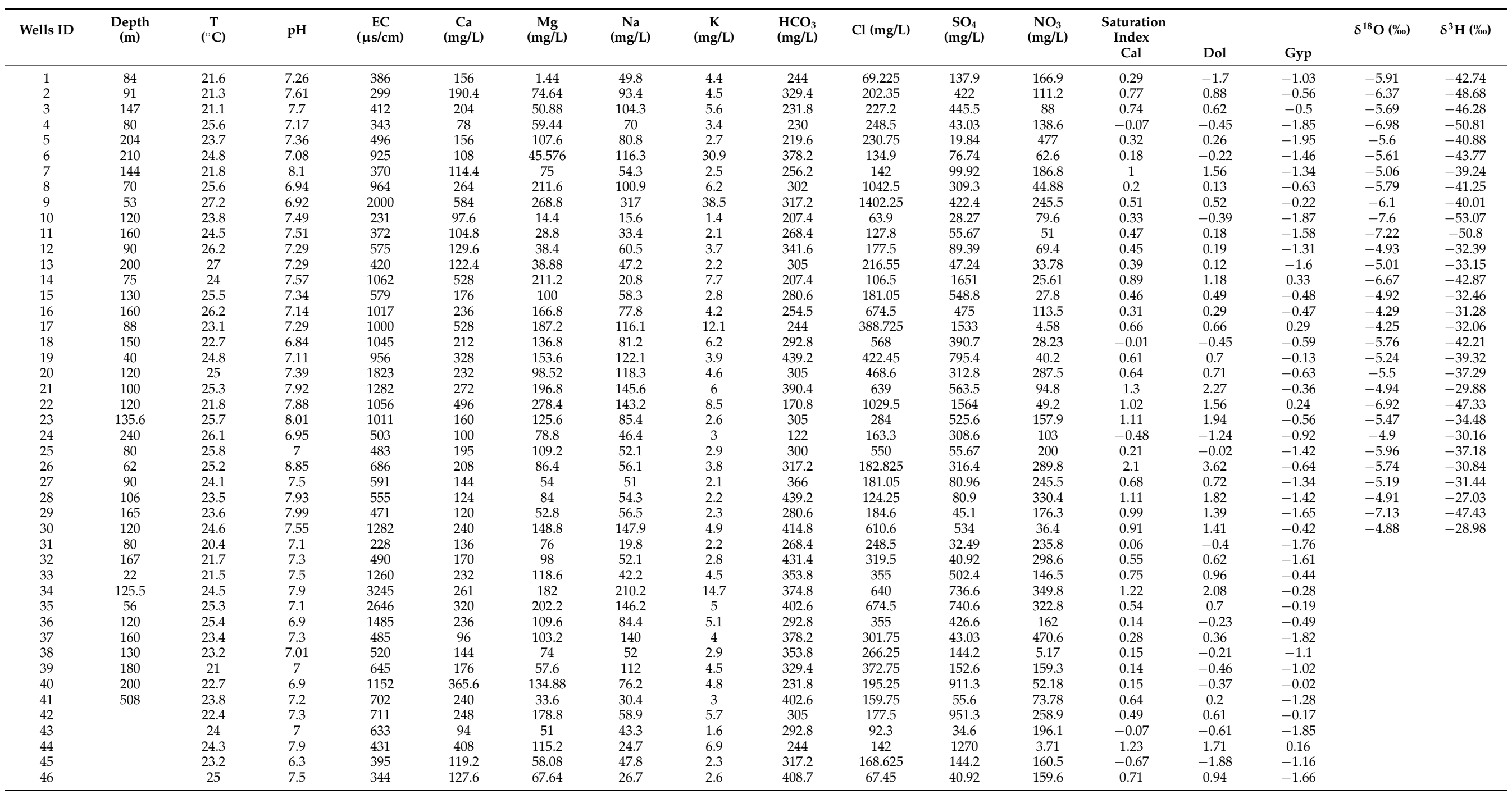


EC values in the captive aquifer are ranging between 228 and $3245 \mu \mathrm{S} / \mathrm{cm}$ (Figure 6b) and increase globally from South to North following the flow direction. The lowest values appear upstream (recharge zone) while the highest values occur downstream close to the Tensift wadi.

\subsection{Main Ionic Character}

The groundwater hydrochemical characteristics of the Ouled BouSbaa plain are shown in Table 1 . The pH of the groundwater in the study area is $6.3 ; 8.85$, and the average value is 7.37; the groundwater is weakly alkaline.

The main cation in groundwater is $\mathrm{Ca}^{2+}$, with a concentration between 94 and $584 \mathrm{mg} / \mathrm{L}$. The average value is $216.99 \mathrm{mg} / \mathrm{L}$. The order of cations concentration is $\mathrm{Ca}^{2+}>\mathrm{Mg}^{2+}>$ $\mathrm{Na}^{+}>\mathrm{K}^{+}$. The main anion of groundwater is $\mathrm{SO}_{4}{ }^{2-}$. Its concentration range is between 34.6 and $1651 \mathrm{mg} / \mathrm{L}$. The mean concentration of $\mathrm{SO}_{4}{ }^{2-}$ is $395.78 \mathrm{mg} / \mathrm{L}$. The order of anion concentration is: $\mathrm{SO}_{4}{ }^{2-}>\mathrm{Cl}^{-}>\mathrm{HCO}_{3}{ }^{-}>\mathrm{NO}_{3}{ }^{-}$.

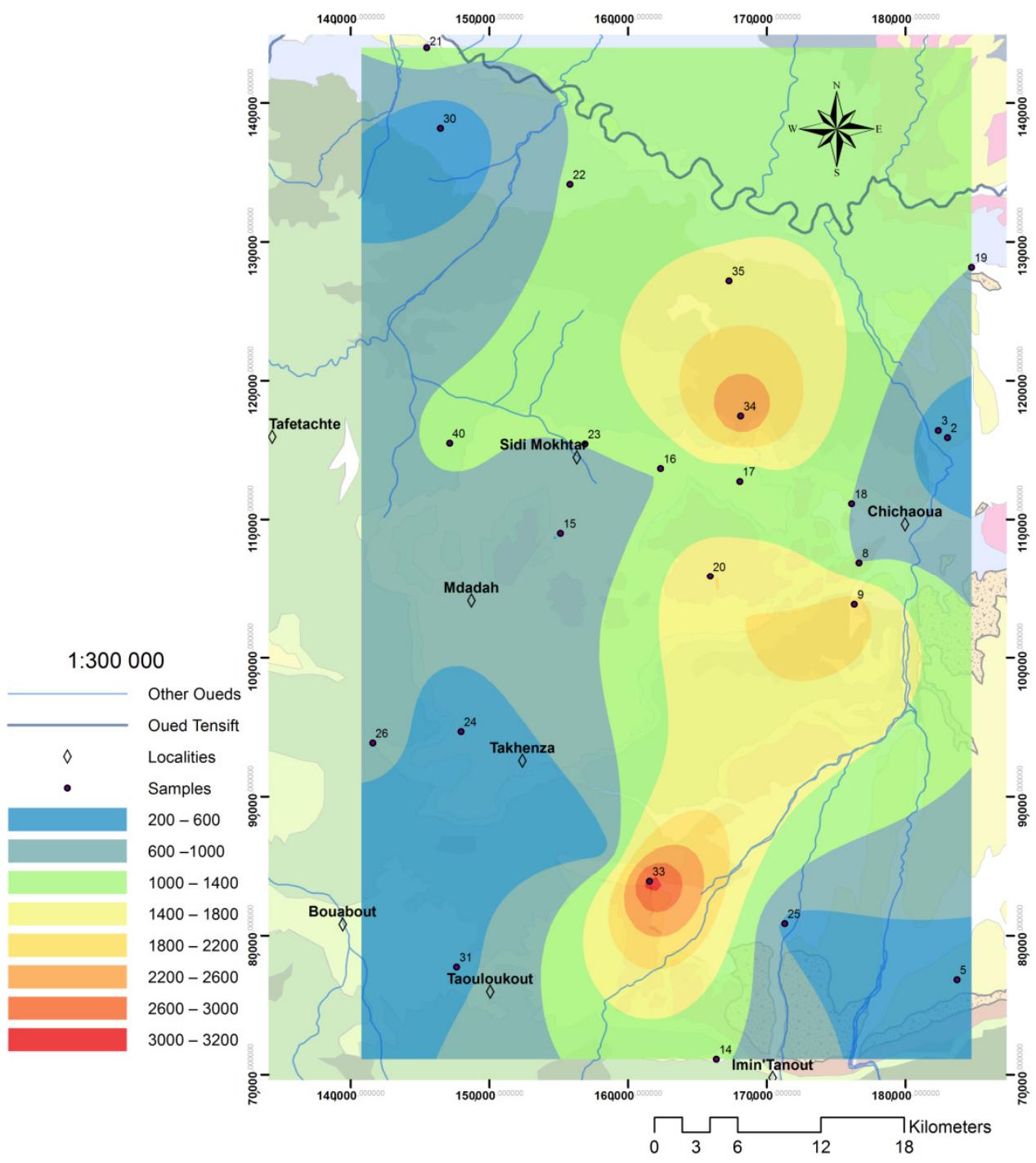

(a)

Figure 6. Cont. 


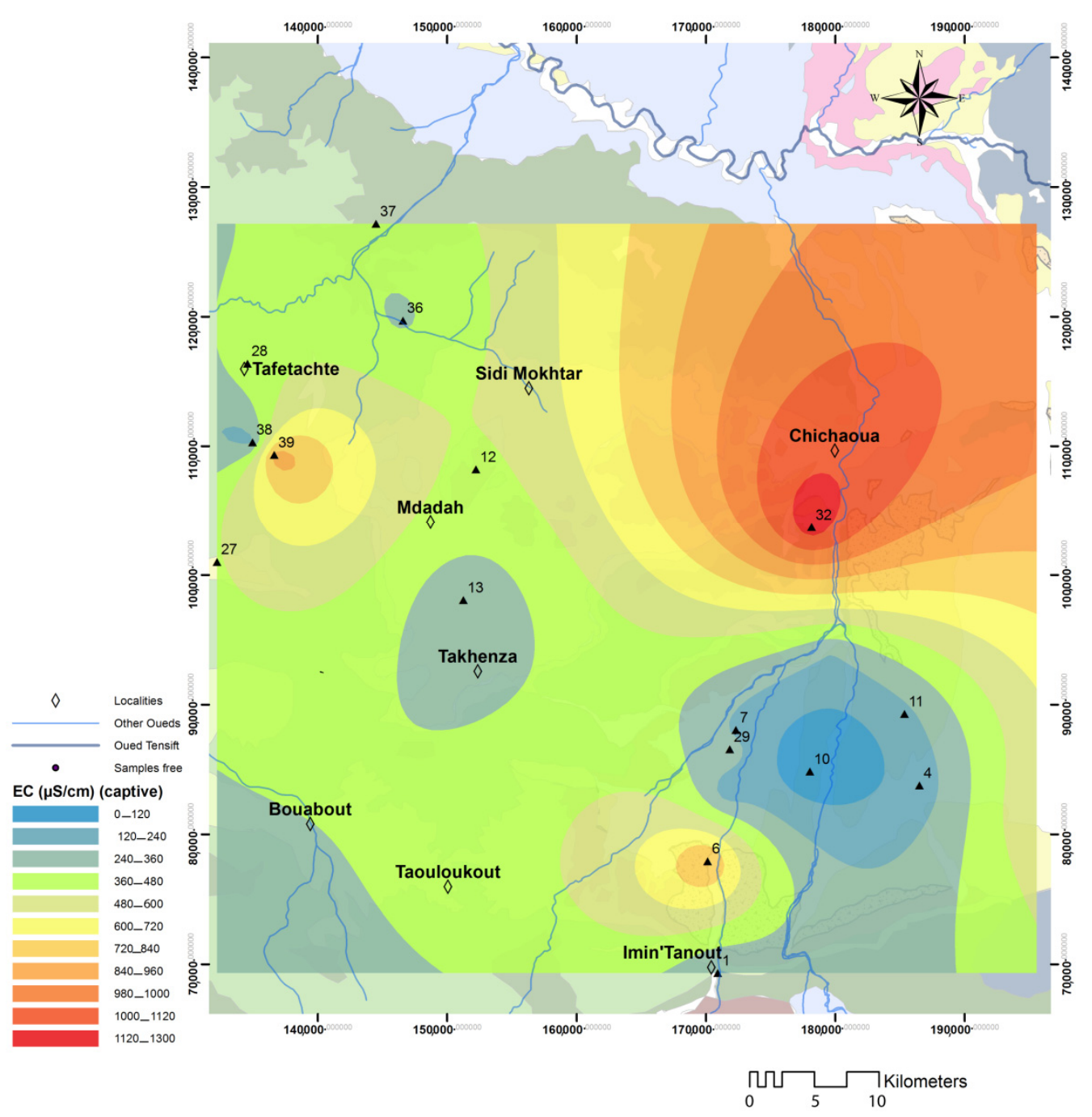

(b)

Figure 6. Spatial distribution of groundwater EC in the study area. (a) In the free aquifer; (b) In the captive aquifer.

It is worth noting that the concentration of $\mathrm{NO}_{3}{ }^{-}$is $3.71 ; 477.0 \mathrm{mg} / \mathrm{L}$, and the average concentration is $152.64 \mathrm{mg} / \mathrm{L}$, with an over-the-standard $(50 \mathrm{mg} / \mathrm{L})$ [9]; rate of $76.1 \%$. It is obvious that groundwater in the area has been seriously polluted by $\mathrm{NO}_{3}{ }^{-}$.

\subsection{Water Types}

To identify the water types in the study area, the contents of analyzed elements were reported on the diagram of Piper (Figure 7) illustrating the existence of different types of facies. The dominant cations were Calcium followed by Magnesium. The anion concentrations show two groups with one dominated by carbonates and chlorides and a second rich in sulfates and chlorides. Thus, there seem to be two different facies with the first one characterized by sulfate and calcium-magnesium representing the confined aquifer of Turonian and one sample from Vraconian. The second of hyper-chlorides and calcium, that represents a mixing between the Quaternary water and the unconfined Turonian to the upstream. 


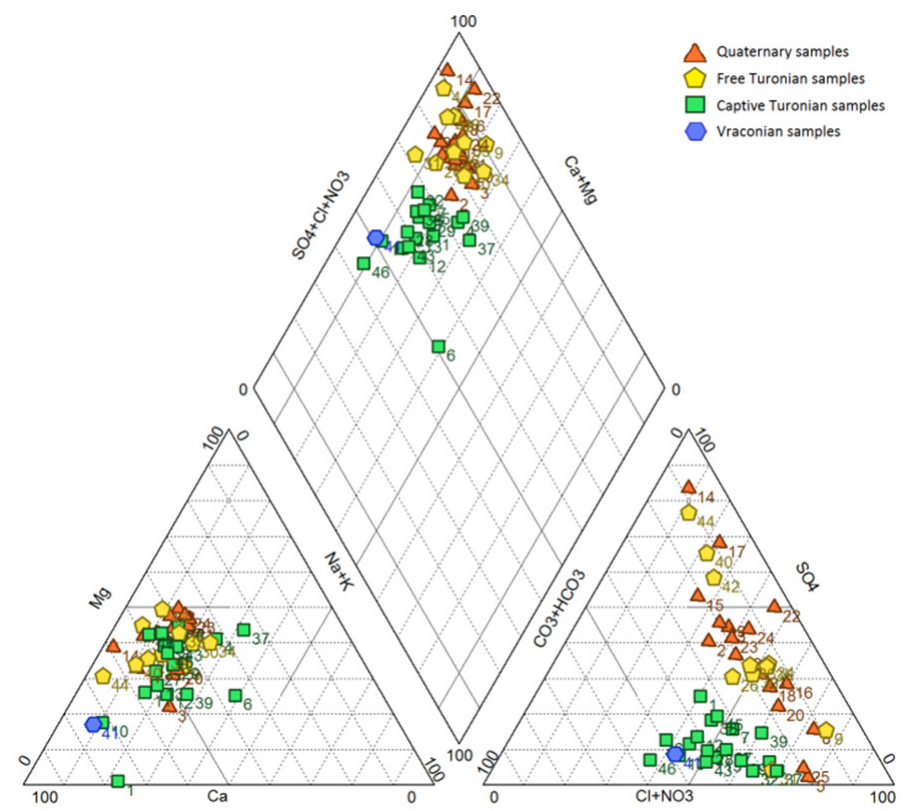

Figure 7. Piper diagram. Major-ion relationships in groundwater in BouSbaâ Basin.

\subsection{Isotopes}

The estimate of aquifers' recharge altitudes is of particular interest where recharge areas are poorly known. Generally, the isotopes of the water molecule (Oxygene-18, Deuterium) are among the most used in aquifer investigations. They are expressed using the Delta notation $(\delta)$, defined by Craig [68] as:

$$
\delta(\%)=\left[\left(\mathrm{R}_{\text {sample }} / \mathrm{R}_{\text {referance }}\right)-1\right] \times 1000
$$

$\mathrm{R}$ is the ratio of isotopic abundance, expressed as ${ }^{18} \mathrm{O} /{ }^{16} \mathrm{O}$ or ${ }^{2} \mathrm{H} /{ }^{1} \mathrm{H}$. Positive values of $\delta$ indicate that the sample is enriched relative to the reference standard and negative values indicate that the sample is depleted.

For Oxygen-18 and Deuterium, the standard corresponds to the average isotopic composition of SMOW (standard mean ocean water), oceanic waters having by definition a value equal to $0 \%$. On a global scale, the Oxygene-18 and Deuterium contents of precipitations that did not undergo evaporation are characterized by a linear relationship [68]. The equation of this line, called the global meteoric water line (GMWL), is written as follows:

$$
\delta \% \text { o }\left({ }^{2} \mathrm{H}\right)=8 \times \delta \% \text { о }\left({ }^{18} \mathrm{O}\right)+10
$$

Thirty groundwater samples were collected in the study area. The sampled points were distributed over the entire area (Figure 8). Stable isotopes values are reported in Table 1.The altitude of the water points ranges between $830 \mathrm{~m}$ (sample 30) and $212 \mathrm{~m}$ (sample 21). Oxygene-18 values range from $-7.60 \%$ (well 10 at $640 \mathrm{~m}$ altitude) to $-4.25 \%$ (well 17 at $374 \mathrm{~m}$ ), those of Deuterium between $-53.07 \%$ (well 10 at $640 \mathrm{~m}$ altitude) and $-27.03 \%$ (well 28 at $412 \mathrm{~m}$ ). The relationship between Deuterium and Oxygene-18 is shown in Figure 9, with the global meteoric water line [68]. All water samples plot along the GMWL or are very close to this line. Some samples below the GMWL show very slight evaporation. 


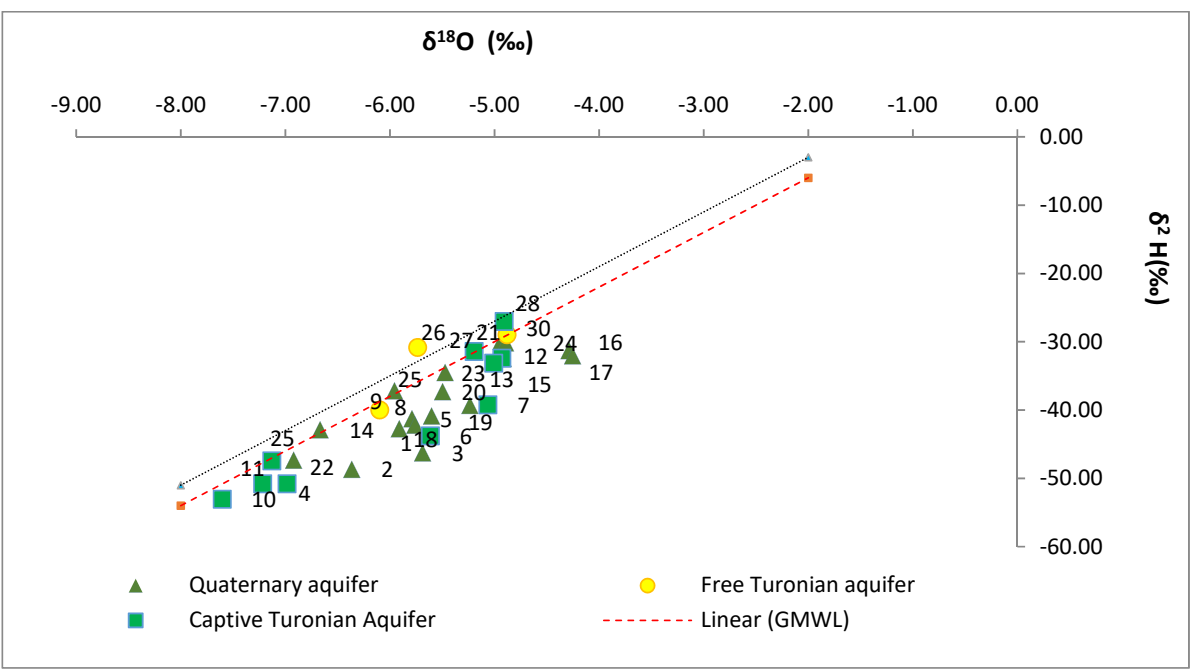

Figure 8. Plot of the levels of $\delta^{18} \mathrm{O}$ versus $\delta^{2} \mathrm{H}$; The samples are sorted according by geographical and system distribution.

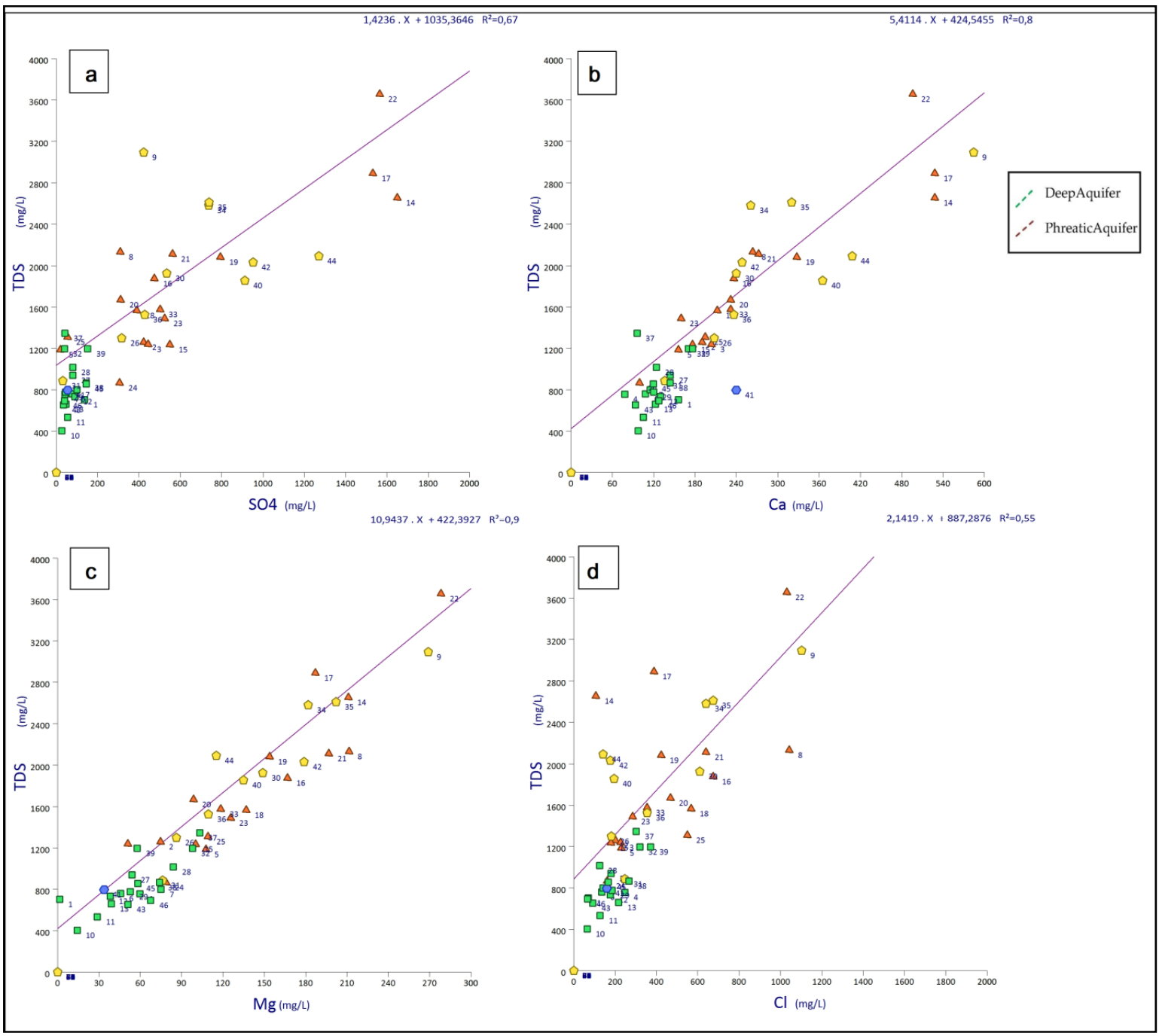

Figure 9. Relationships between the dissolved major ions versus the total dissolved solids for all the samples. (a) $\mathrm{SO}_{4}$, (b) $\mathrm{Ca}$, (c) $\mathrm{Mg}$, (d) $\mathrm{Cl}$. 


\section{Discussion}

In general, the groundwater level in the study area is quite deep (22 to $240 \mathrm{~m}$ below ground level). Even with a deep aquifer, the groundwater flow is controlled by surface topography. In the eastern part, groundwater flows towards the north and in the western part, towards the south-west. As expected, the hydraulic gradient is low in the plains and high in the pediment zones in the north and the south. Collected groundwater samples are divided into three groups based on the type of geological formation the wells encountered. As the majority of the samples ( 28 no.) are distributed within the Free Aquifer, 18 samples represent the Quaternary formation, 10 samples are from the Turonian formation, and the last 17 points belong to Turonian captive aquifer.

The analysis of EC (Figure 7) indicates that the quality of the water in the captive and the free aquifers were mostly good except for well 34 with a value of $3245 \mu \mathrm{S} / \mathrm{cm}$ exceeding the Moroccan and OMS standards. The lowest values of conductivity were observed around the Seksaouawadi (upstream of Chichaoua's Wadi). The low EC freshwater of this stream feeds the aquifer according to [69].The highest EC values were recorded north of Chichaoua and Sidi Mokhtar probably resulting from leaching related to raw wastewater discharge and the surrounding fields [70].

The values of total dissolved solids (TDS) vary between 508 and $3740 \mathrm{mg} / \mathrm{L}$. The concentration of ions varies widely with Chlorides from 63.9 to $1402.25 \mathrm{mg} / \mathrm{L}$, Calcium from 78 to $584 \mathrm{mg} / \mathrm{L}$, Sodium from 19.84 to $317 \mathrm{mg} / \mathrm{L}$, sulfates from 19To $1651 \mathrm{mg} / \mathrm{L}$, magnesium from 1.44 to $278.4 \mathrm{mg} / \mathrm{L}$, and nitrates from 3.71 to $477 \mathrm{mg} / \mathrm{L}$.

To better clarify the origins of mineralization, Figure 10 reports correlation between TDS and major elements. These correlations reflect the main elements contributing to groundwater salinity.The graphs show a clear distinction of two groups of samples. Those originating from the deep aquifers (captive Turonian) with a low salinity compared to those originating from the Quaternary and unconfined Turonian aquifers. This is consistent with the interaction above of the Piper diagram (Figure 8).

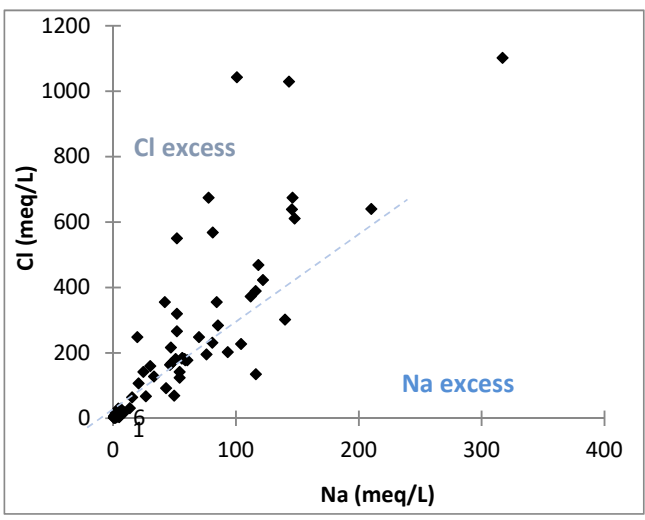

(a)

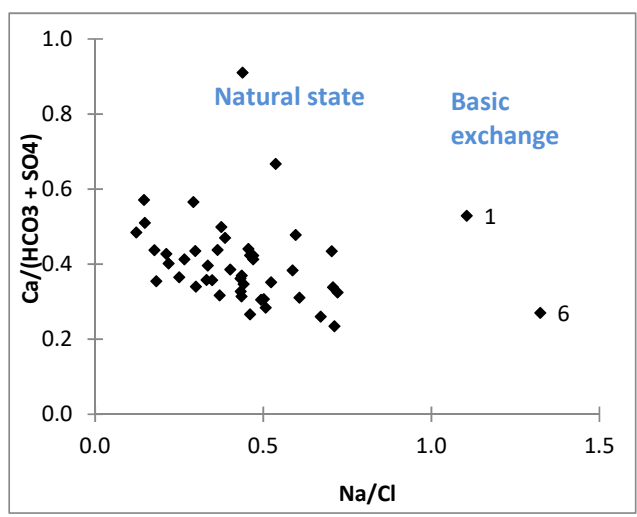

(b)

Figure 10. (a) Relationships between Sodium and Chloride; (b) Diagram of the cation exchange process.

However, (Figure 10) showed that despite the high saturation index of carbonates, they are the evaporite formations that correlate better with minerals in groundwater samples. Hence, sodium and chlorides originated from the dissolution of halite contained in Triassic evaporates and also from de fertilizers as indicated by the spatial distribution map of EC [71-73].

Water is in equilibrium with a mineral when the salinity index Is $=0$, under-saturated when Is $<0$, and over-saturated when Is $>0[74,75]$. The graph of the salinity index (Figure 11) shows that minerals with carbonates are in saturation while the minerals of evaporites are under-saturated. 


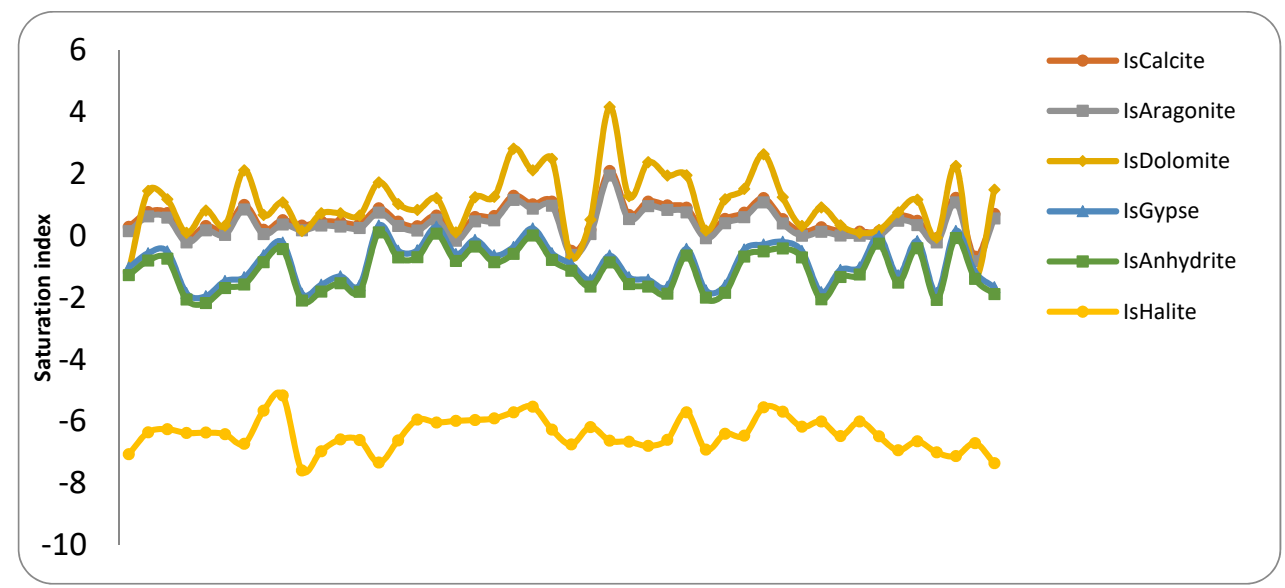

Figure 11. Variation of the different Minerals saturation indexes.

The concentrations of $\mathrm{SO}_{4}{ }^{2-}, \mathrm{Cl}^{-}, \mathrm{Ca}^{2+}$ and $\mathrm{Na}^{+}$presented a very similar distribution. The highest concentrations occurred in the Northern part of the aquifer. The concentrations of Calcium and Magnesium may originate from the dissolution of carbonate formations of the Cenomanian-Turonian and dolomites of lower Cretaceous in addition to leaching from encrusted salts but in majority from the dissolution of evaporates; Gypsum and Anhydrites in Cenomanian-Turonian and Permo-Triassic halite (Figure 12c), [76]. Calcium ions also originated from trickling waters of Chichaouawadi and AssifElmal and springs upstream of the Plio-Quaternary water table [77]. Nevertheless, the highest values of Magnesium and Sulfates can be justified by the presence of gypsiferous marls from evaporite deposits. Sodium and chlorides were found in the Southeast and Northwest parts of the aquifer. Chlorides can have many origins such as sandy gypsiferous clays, gypsiferous marls, and halite.

The graph of the evolution of $\mathrm{Cl}^{-}$as a function of Na+ (Figure 12d) shows that they are correlated with an excess of chloride ions in some points. The projection of all samples on the $\mathrm{Na}+/ \mathrm{Cl}^{-}$and $\mathrm{Ca}^{2+} /\left(\mathrm{HCO}_{3} \mathrm{SO}_{4}\right)$ diagram showed that 44 of the 46 water samples were in the natural state.

As the free aquifer and the captive are segregated by an impermeable layer, the nitrates contamination mainly affects the water table, not the deep aquifer. It is therefore essential to establish its spatial distribution to know its source.

The high concentration of nitrates is certainly related to human activities including the presence in the area of many landfills with leachates, domestic wastewater effluents, septic tanks, and larges agricultures exploitations using big amounts of fertilizer that can infiltrate the groundwater as shown in the special distribution of the Nitrates map (Figure 13) [78].
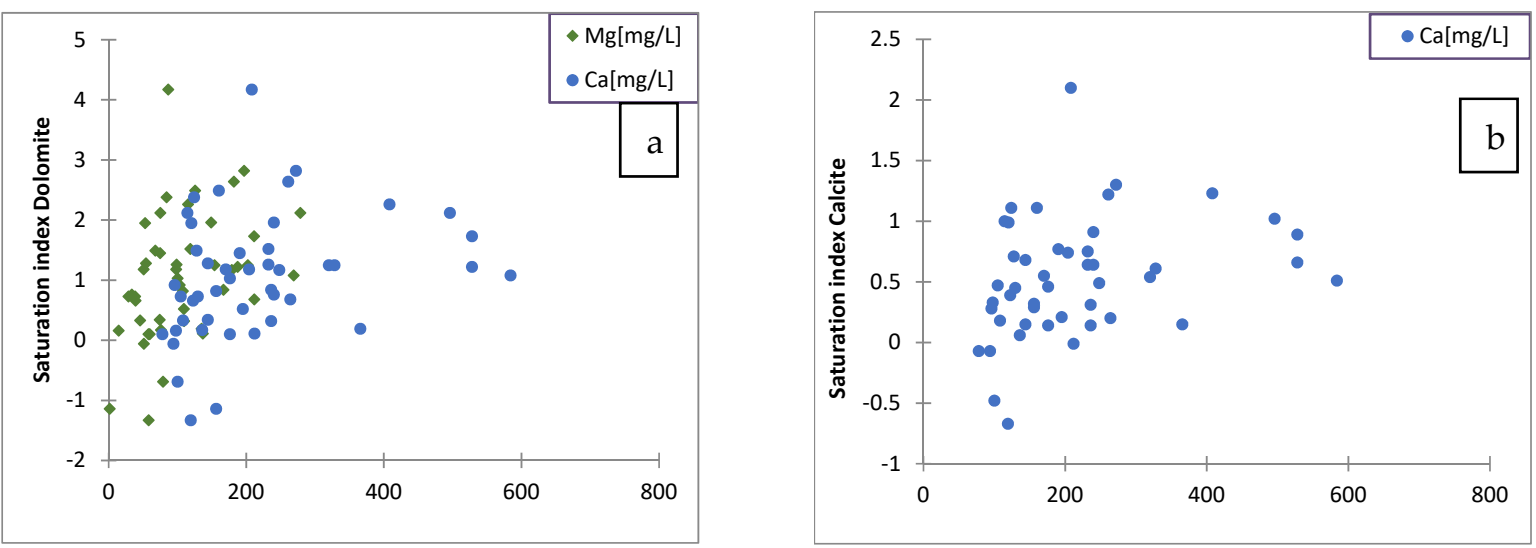

Figure 12. Cont. 

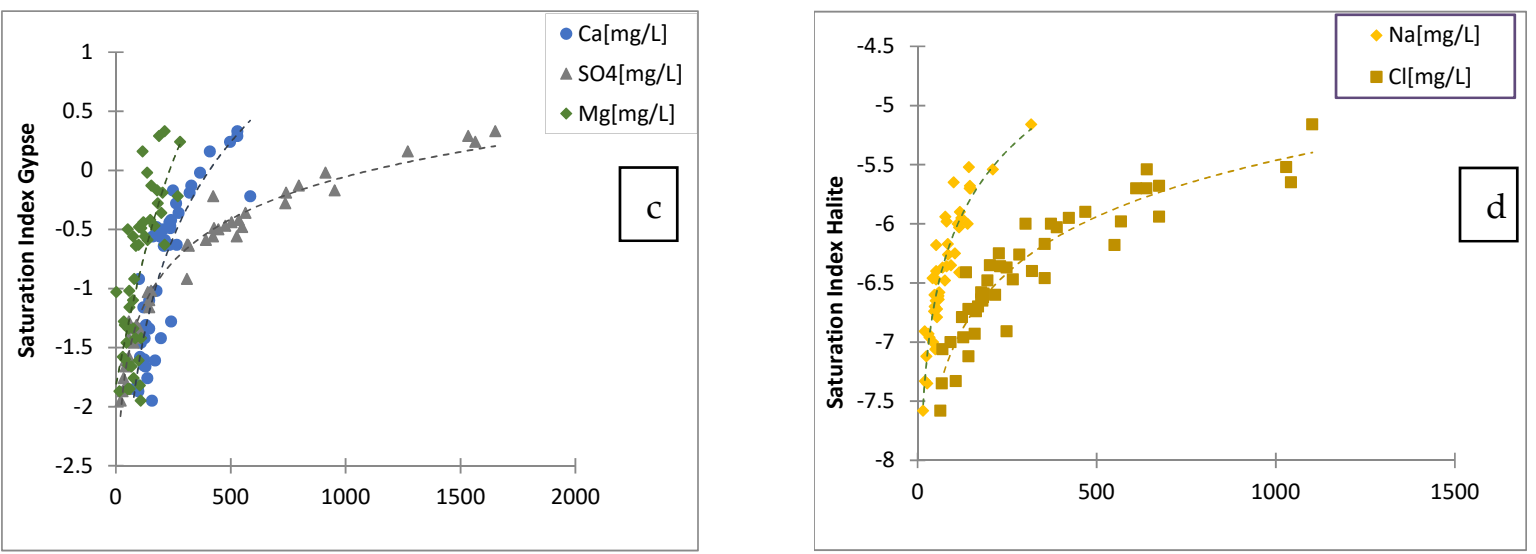

Figure 12. Correlation between the saturation indexes and dissolved major ions (a) $\mathrm{Mg}$, (b) $\mathrm{Ca}$, (c) $\mathrm{Mg}$, (d) $\mathrm{Cl}$.

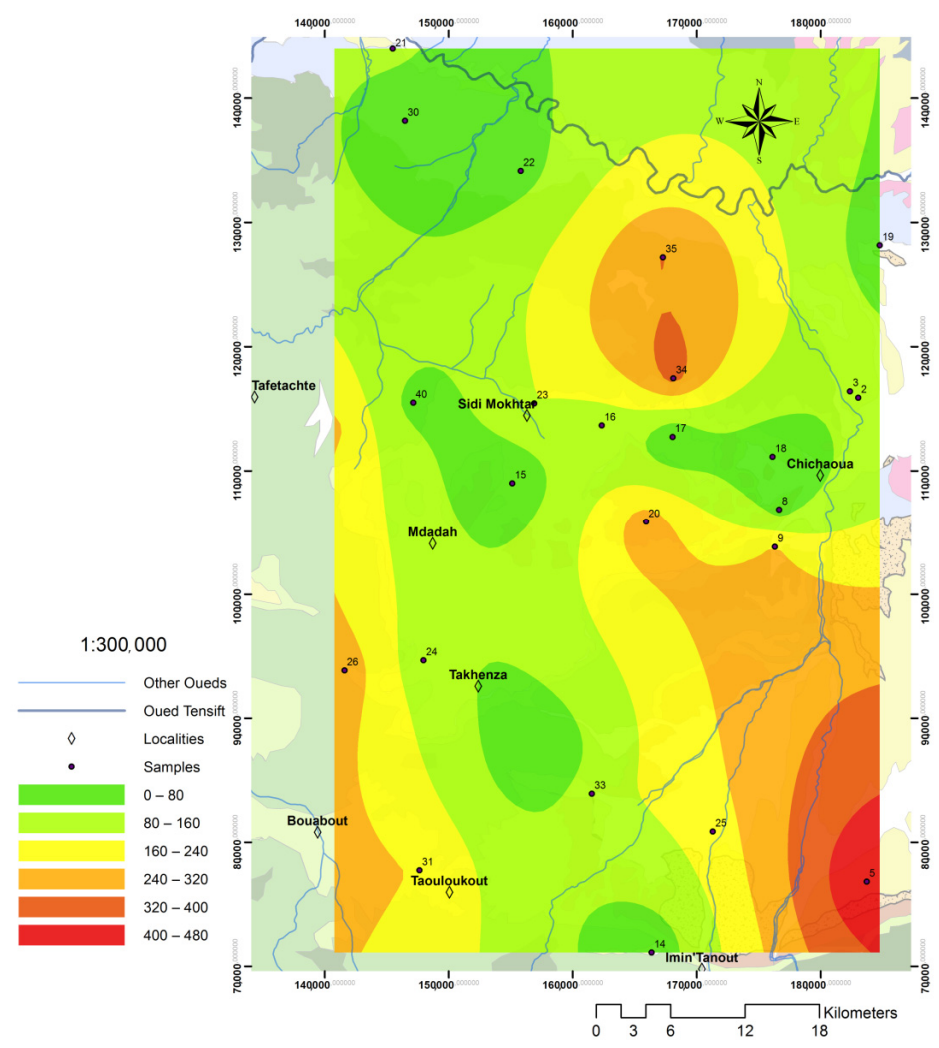

Figure 13. Spatial distribution of the Nitrates in the study area.

\subsection{Isotopes}

Stable isotopes of the water molecules can be used to understand the source of groundwater recharge, connectivity between aquifers [54,78], groundwater flow regime, and aquifer recharge $[79,80]$.

It often represents the most effective tool to study the possibility of a connection between waters of different origins [81] since they are conserved as soon as they reach the level of the aquifer. Previous observations in the study area have shown heterogeneous values $\left(-24.4 \%\right.$ to $-110.7 \%$ for $\mathrm{d}^{2} \mathrm{H}$ and $-5.5 \%$ to $-15.6 \%$ for $\mathrm{d}^{18} \mathrm{O}$ ) representing the isotopic variation of rainfall from the plain to the High Atlas Mountains.

Based on the values of $\delta^{18} \mathrm{O}$ and $\delta^{2} \mathrm{H}$ and their relative position to GMWL (Figure 8), our samples could be divided into two groups:

- The first with points $14,21,25,26,27,28,29$, and 30 located a little above the GMWL, which may indicate that the trickled waters were not submitted to evaporation; 
- The second that encloses all the remaining samples appeared below the GMWL and seems to be partitioned by evaporation.

The analysis of the relation between oxygen 18 and the depth of groundwater samples (Figure 14) showed that the evaporation affects mostly the shallow groundwater samples. The origin of the deep groundwater samples with low levels of $\delta^{18} \mathrm{O}$ is distant coming from the high altitudes. This confirms the hypothesis that the aquifers are fed by the junction of the two aquifers at the High Atlas piedmont.

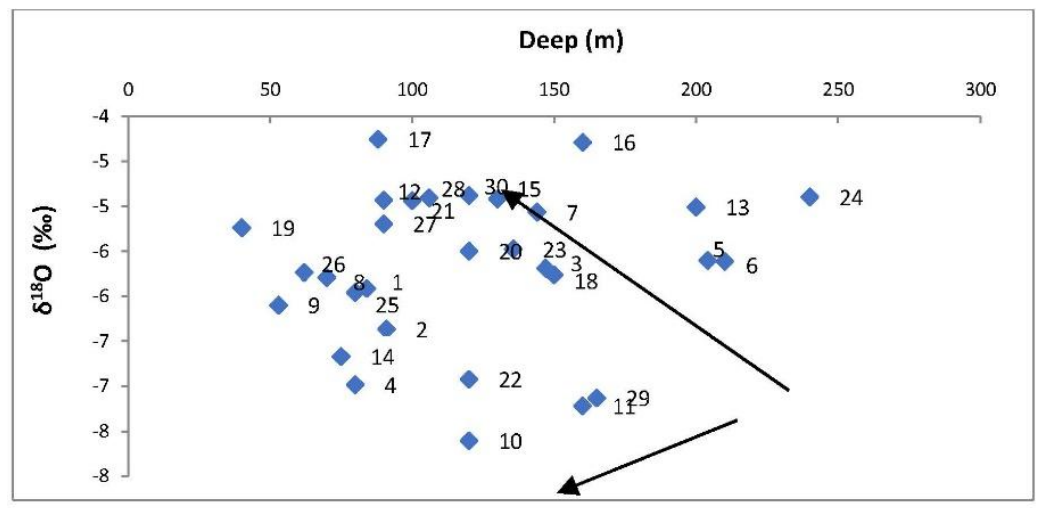

Figure 14. $\delta^{18} \mathrm{O}$ versus the depth of the boreholes.

The graph of $\delta^{18} \mathrm{O}$ versus chloride levels (Figure 15) that can explain the different processes such as groundwater mixing and halite dissolution $[82,83]$, showed two trends. The first, characterized with high chloride values resulting from the leaching of evaporite formations and the second with low values shows that the origin is far away.

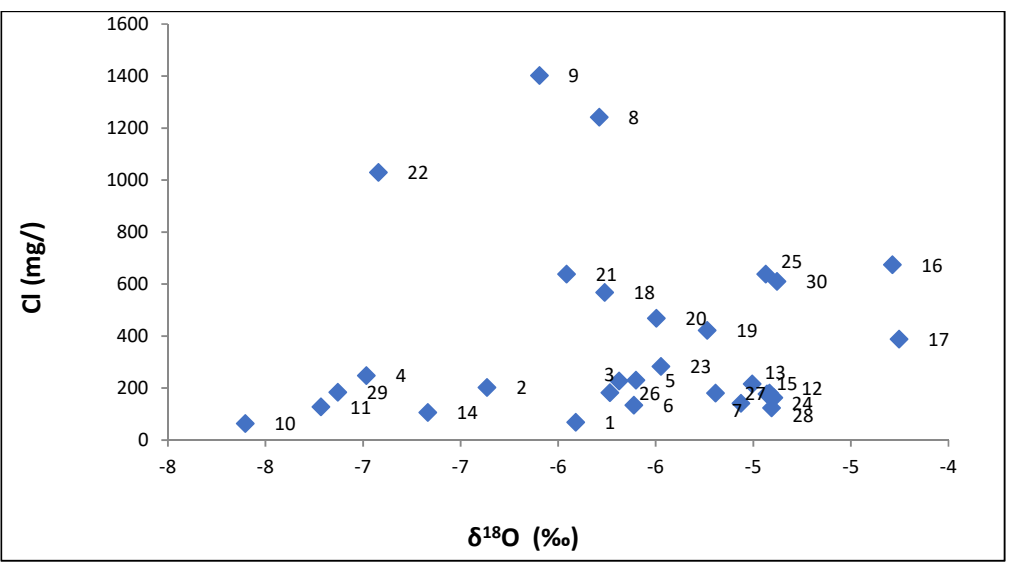

Figure 15. Plot of the levels $\delta^{18} \mathrm{O}$ versus the concentration of $\mathrm{Cl}^{-}$.

Nitrate contamination of groundwater is a growing problem worldwide and constitutes a major challenge to drinking water supplies dependent on groundwater [84]. To check the sources of the nitrates, several patterns have been illustrated in Figures 16 and 17. According to Figure 16a, several samples represent high nitrates values associated with high ${ }^{18} \mathrm{O}$ values. These results indicate that the nitrates leached from the land surface to groundwater via infiltration. The irrigation water is marked by enrichment in $\delta^{18} \mathrm{O}$ due to considerable evaporation at the surface and a concentration of $\mathrm{NO}_{3}{ }^{-}$more or less high depending on the degree of fertilizer use. Since we have a significant correlation between $\delta^{18} \mathrm{O} \mathrm{H}_{2} \mathrm{O}$ and $\mathrm{NO}_{3}$-in general, this suggests that irrigation water return is an important source of nitrate. 

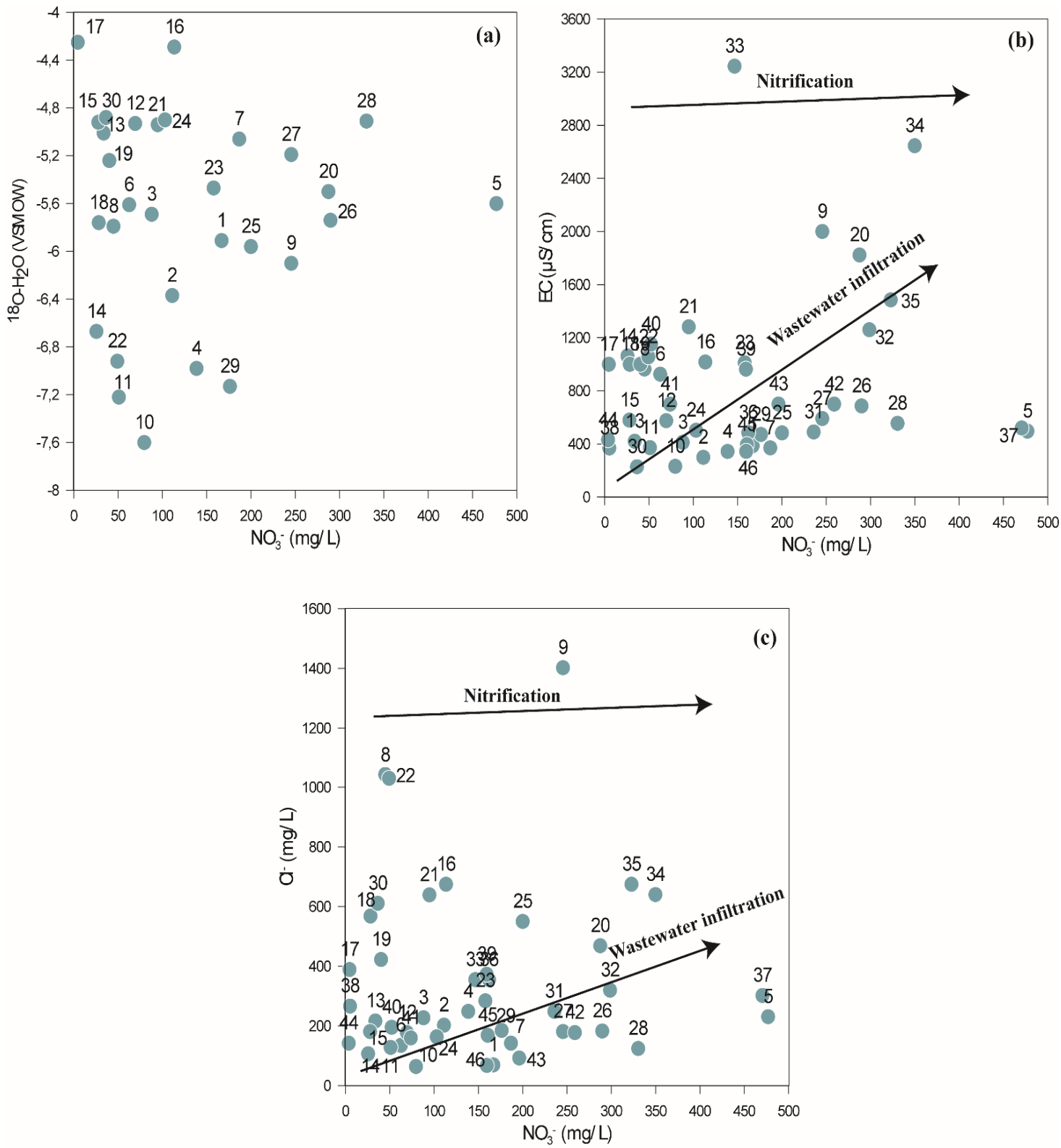

Figure 16. Correlation between Nitrates and: (a) ${ }^{18} \mathrm{O},(\mathbf{b}) \mathrm{EC},(\mathbf{c}) \mathrm{Cl}^{-}$.



Figure 17. $\delta^{18} \mathrm{O}$ versus the Altitude. 
As shown in Figure 16b,c, CL and EC have a constant trend with increasing $\mathrm{NO}_{3}$. Increased $\mathrm{NO}_{3}{ }^{-}$in groundwater without influencing other variables is evidence that infiltration of polluted water from the surface is mixing with mineralized groundwater. Figure 16 indicates that waste infiltration contributes significantly to nitrate pollution of water.

\subsection{Charging Altitude}

In the context of the evolution of groundwater resources in an arid to semi-arid zone combined with increasing socio-economic development which has led to overexploitation of the aquifer; it is necessary to locate the feeding areas.

From the isotopic composition of the water (Figure 17), we can calculate the average water supply altitude [85]. For this, it is necessary to calculate the regional altitudinal gradient. However, the lack of data in $\mathrm{SO}_{4}$ and ${ }^{2} \mathrm{H}$ on rainfall in the study area led us to synthesize previous studies ... in order to obtain a gradient of 0.25 pr per $100 \mathrm{~m}$ for ${ }^{18} \mathrm{O}$.

The projection of the sample points made it possible to locate the recharge altitudes between $570 \mathrm{~m}$ and $1600 \mathrm{~m}$ for the free aquifer, and $800 \mathrm{~m}$ and $1900 \mathrm{~m}$ for the captive aquifer. This confirms the feeding by the connection of the Turonian aquifer in the free Plioquaternary aquifer in the foothills of the High Atlas.

\section{Conclusions}

The groundwater flow in the study's area is controlled by surface topography; groundwater flows towards the north in the eastern part and in the western part, towards the south-west. The quality of the water in the area was mostly good, except for well 34 with a value of $3245 \mu \mathrm{S} / \mathrm{cm}$, exceeding the Moroccan and OMS standards, probably resulting from leaching related to raw wastewater discharge and the surrounding fields.

According to the analysis and Piper diagram, samples originating from the deep aquifers (captive Turonian) have a low salinity compared to those originating from the Quaternary and unconfined Turonian aquifers.

Hence, the geochemical composition of the groundwater in the area shows that minerals mostly originated from the water-rock interaction such as the dissolution of halite contained in permo-Triassic evaporates the sandy gypsiferous clays, the gypsiferous marls and Gypsum and Anhydrides from the Cenomanian-Turonian. Entropic activities such as landfills with leachates, domestic wastewater effluents, and the use of fertilizer in agriculture generate high concentrations of nitrates.

For the values of $\delta^{18} \mathrm{O}$ and $\delta^{2} \mathrm{H}$ and their relative position to GMWL, our samples could be divided into two groups, the first where the trickled waters were not subjected to evaporation and the second encompassing all the remaining samples partitioned by evaporation.

The analysis of the relation between oxygen 18 and the depth of groundwater samples showed that the evaporation affects mostly the shallow groundwater samples. The origin of the deep groundwater samples with low levels of $\delta^{18} \mathrm{O}$ is distant coming from the high altitudes. This confirms the hypothesis that the aquifers are fed by the junction of the two aquifers at the High Atlas piedmont.

The analysis of the isotopes in addition to the other corposants and the altitude recharge confirm that showed two trends. The first, characterized by high chloride values resulting from the leaching of evaporite formations, and the second with low values showing that the origin is far away.

This confirms the feeding by the connection of the Turonian aquifer in the free Plioquaternary aquifer in the foothills of the High Atlas.

Author Contributions: Conceptualization, R.T. and A.E.M.; Data curation, R.T.; Formal analysis, R.T.; Funding acquisition, R.T. and A.E.M.; Investigation, R.T.; Methodology, R.T. and A.E.M.; Project administration, A.E.M.; Resources, R.T., A.E.M.and L.B.; Software, R.T.; Supervision, A.E.M.; Validation, A.E.M., D.C., M.E. and L.B.; Visualization, M.E. and F.E.E.G.; Writing-original draft, R.T.; Writing-review \& editing, R.T., A.E.M., M.E. and L.B. All authors have read and agreed to the published version of the manuscript. 
Funding: This research received no external funding.

Institutional Review Board Statement: Not applicable.

Informed Consent Statement: Not applicable.

Conflicts of Interest: The authors declare no conflict of interest.

\section{References}

1. Hssaisoune, M.; Bouchaou, L.; Sifeddine, A.; Bouimetarhan, I.; Chehbouni, A. Moroccan Groundwater Resources and Evolution with Global Climate Changes. Geosciences 2020, 10, 81. [CrossRef]

2. El Mandour, A.; El Yaouti, F.; Fakir, Y.; Zarhloule, Y.; Benavente, J. Evolution of groundwater salinity in the unconfined aquifer of Bou-Areg, Northeastern Mediterranean coast, Morocco. Environ. Geol. 2008, 54, 491-503. [CrossRef]

3. Wen, X.H.; Wu, Y.Q.; Wu, J. Hydrochemical characteristics of groundwater in the Zhangye basin, North western China. Environ. Geol. 2008, 55, 1713-1724. [CrossRef]

4. Milnes, E. Process-based groundwater salinisation risk assessment methodology: Application to the Akrotiri aquifer (Southern Cyprus). Hydrol. J. 2011, 399, 29-47. [CrossRef]

5. Hamzaoui-Azaza, F.; Tlili-Zrelli, B.; Bouhlila, R.; Gueddari, M. An integrated statistical methods and modeling minerals-water interaction to identifying hydrochemical processes in groundwater in southern Tunisia. Chem. Speciat. Bioavailab. 2013, 25, 165-178. [CrossRef]

6. El Alfy, M.; Lashin, A.; Al Arifi, N.; Al Bassal, A. Groundwater characteristics and pollution Assessment using integrated Hydrochemical investigations GIS and multivariate geostatistical techniques in arid area. Water Resour. Manag. 2015, 29, 5593-5612. [CrossRef]

7. Fakir, Y.; Zerouali, A.; Aboufirassi, M.; Bouabdelli, M. Potential exploitation and salinity of aquifers, Chaouia coast, Atlantic shoreline, Morocco. J. Afr. Earth Sci. 2001, 32, 791-801. [CrossRef]

8. Bouchaou, L.; Michelot, J.L.; Vengosh, A.; Hsissou, Y.; Qurtobi, M.; Gaye, C.B.; Bullen, T.D.; Zuppi, G.M. Application of multiple isotopic and geochemical tracers for investigation of recharge, salinization, and residence time of water in the Souss-Massa aquifer, southwest of Morocco. J. Hydrol. 2008, 352, 267-287. [CrossRef]

9. El Yaouti, F.; El Mandour, A.; Khattach, D.; Benavente, J.; Kaufmann, O. Salinization processes in the unconfined aquifer of Bou-Areg (NE Morocco): A geostatistical, geochemical, and tomographic study. Appl. Geochem. 2009, 24, 16-31. [CrossRef]

10. Razoki, B. Mise en Place d'un Systeme de Gestion de Base de Donnees Pour la Gestion des Ressources en Eaux Souterraines de la Nappe du Haouz. (Meseta Occidental, Maroc). Ph.D. Thesis, Cadi Ayyad University, Marrakech, Morocco, $2001 ;$ p. 6.

11. Seif-Ennasr, M.; Zaaboul, R.; Hirich, A.; Caroletti, G.N.; Bouchaou, L.; El Morjani, Z.E.A.; Beraaouz, E.H.; McDonnell, R.A.; Choukr-Allah, R. Climate change and adaptive water management measures in ChtoukaAit Baha region (Morocco). Sci. Total Environ. 2016, 573, 862-875. [CrossRef]

12. Milnes, E.; Perrochet, P.; Renard, P.; Cornaton, F. (Eds.) Framework for a process-based salinisation risk assessment methodology: Solute recycling versus primary groundwater salinisation. In Proceedings of the IAHR-GW2006 Meeting, Toulouse, France, 12-14 June 2006.

13. Peragón, J.M.; Pérez-Latorre, F.J.; Delgado, A. A GIS-based quality assessment model for olive tree irrigation water in southern Spain. Agric. Water Manag. 2015, 148, 232-240. [CrossRef]

14. Elgettafi, M.; Elmandour, A.; Himi, M.; Casas, A. The use of environmental markers to identify groundwater salinization sources in a Neogene basin, Kert aquifer case, NE Morocco. Int. J. Environ. Sci. Technol. 2013, 10, 719-728. [CrossRef]

15. Frind, E.O.; Muhammad, D.S.; Molson, J.W. Delineation of three dimensional well capture zones for complex multiaquifer systems. Ground Water 2002, 40, 586-598. [CrossRef] [PubMed]

16. Chellai, E.H. Evolution Geodynamique des Corps Sedimentairesmesoecenozoique du Haut Atlas de Marrakech. Ph.D. Thesis, Faculty of Sciences, Semlalia, Marrakech, 1995; p. 514.

17. Peragón, J.M.; Delgado, A.; Rodríguez, J.A.; Pérez-Latorre, F.J. A GIS-based decision tool for reducing salinization risks in olive orchards. Agric. Water Manag. J. 2016, 166, 33-41. [CrossRef]

18. Pulido-Leboeuf, P.; Pulido-Bosch, A.; Calvache, M.L.; Vallejos, A.; Andreu, J.M. Strontium, $\mathrm{SO}_{4} / \mathrm{Cl}_{\text {and }} \mathrm{Mg} / \mathrm{Ca}_{2}$ ratios as tracers for the evolution of sea water into coastal aquifers: The example of Castell de Ferro-aquifer. C.R. Geosci. 2003, 335, 1039-1048. [CrossRef]

19. Risacher, F.; Ftriz, B. Origin of salts and brine evolution of bolivian and chileansalars. Aquat. Geochem. 2009, 15, 123-157. [CrossRef]

20. Lucas, Y.; Schmitt, A.D.; Clement, A.; Ftriz, B.; Elsass Ph Durand, S. Geochemical tracing and hydrogeochemical modeling of water-rock interaction during salinization of alluvial groundwater (Upper Rhine Valley, France). Appl. Geochem. J. 2010, 25, 1644-1663. [CrossRef]

21. Warner, N.R.; Kresse, T.M.; Hays, P.D.; Down, A.; Karr, J.D.; Jackson, R.B.; Vengosh, A. Geochemical and isotopic variations in shallow groundwater in areas of the Fayetteville Shale development, north-central Arkansas. Appl. Geochem. 2013, 35, 207-220. [CrossRef] 
22. Rochdane, S.; El Mandour, A.; Jaffal, M.; Himi, M.; Casas, A.; Amrhar, M.; Karroum, M. Geometriedel'aquifere du Haouz oriental et Tassaout amont. Maroc occidental: Approche geophysique et hydrogeologique. Hydrol. Sci. J. 2014, 6, 33-144. [CrossRef]

23. Ait Brahim, Y.; Benkaddour, A.; Agoussine, M.; Ait Lemkademe, A.; Al Yacoubi, L.; Bouchaou, L. Origine et salinité des eaux souterraines à partir de l'interprétation des données d'analyse dans la zone minière d'Oumjrane, sud-est du Maroc. Environ. Earth Sci. 2015, 74, 4787-4802. [CrossRef]

24. Hsissou, Y.; Mudry, J.; Bouchaou, L.; Chauve, P.; Mania, J. Use of chemical tracy to study acquisition modality of mineralization and behaviour of unconfined groundwater under semi-arid climate: The case study of the Souss plain (Morocco). Environ. Geol. 2002, 42, 672-680.

25. Capaccioni, B.; Didero, M.; Paletta, C.; Didero, L. Saline intrusion and refreshening in multilayer coastal aquifer in the Catania Plain (Sicily, southern Italy): Dynamics of degradation processes according to the hydrochemical characteristics of groundwaters. Hydrol. J. 2005, 307, 1-16. [CrossRef]

26. De Montety, V.; Radakovitch, O.; Vallet-Coulomb, C.; Blavoux, B.; Hermitte, D.; Valles, V. Origin of groundwater salinity and hydrogeochemical processes in a confined coastal aquifer. Case of the Rhone delta (Southern France). Appl. Geochem. J. 2008, 23, 2337-2349. [CrossRef]

27. Bouchaou, L.; Michelot, J.L.; Qurtobic, M. Origine et temps de séjour des eaux souterraines dans le bassin du Tadla (Maroc) à l'aide de multiples outils isotopiques et géochimiques. J. Hydrol. 2009, 379, 323-338. [CrossRef]

28. Zghibi, A.; Merzougui, A.; Lahcen, Z.; Tarhouni, J. Interaction between groundwater and seawater in the coastal aquifer of Cap-Bon in the semi-arid systems (northeast of Tunisia). Carbonates Evaporites 2014, 29, 309-326. [CrossRef]

29. Fadili, A.; Najib, S.; Mehdi, K.; Riss, J.; Makan, A.; Boutayed, K.; Guessir, H. Hydrochemical features and mineralization processes in coastal groundwater of Oualidia. Morroco. Afr. Earth Sci. J. 2016, 116, 233-247. [CrossRef]

30. Chafouq, D.; El Mandour, A.; Elgettafi, M.; Himi, M.; Chouikri, I.; Casas, A. Hydrochemical and isotopic characterization of groundwater in the Ghis-Nekor plain (Northern Morocco). J. Afr. Earth Sci. 2017, 139, 1-13. [CrossRef]

31. Zammouri, M.; Siegfried, T.; El-Fahem, T.; Kriâa, S.; Kinzelbach, W. Salinization of groundwater in the Nefzawa oases region, Tunisia: Results of a regional-scale hydrogeologic approach. Hydrogeol. J. 2007, 15, 1357-1375. [CrossRef]

32. Boutaleb, S.; Bouchaou, L.; Mudry, J.; Hsissou, Y.; Chauve, P. Effects of lithology on quality of water resources. The case of ouedIssen (Western Upper Atlas, Morocco). Hydrogeol. J. 2000, 8, 230-238. [CrossRef]

33. Al-Harbi, O.; Hussain, G.; Khan, M.M. Hydrogeochemical processes and isotopic characteristics of inland Sabkha, Saudi Arabia. Asian Earth Sci. J. 2008, 1, 16-30. [CrossRef]

34. Farid, I.; Trabelsi, R.; Zouari, K.; Abid, K.; Ayachi, M. Hydrogeochemical processes affecting groundwater in an irrigated land in Central Tunisia. Environ. Earth Sci. 2013, 68, 1215-1231. [CrossRef]

35. Bel Hadj Salem, S.; Chkir, N.; Zouari, K.; Cognard-Plancq, A.L.; Valles, V. Hydrochemical and isotope evidence of groundwater contamination of cultivated fields of semi-arid environments in Tunisia. Arid Land Manag. J. 2012, 26, 181-199. [CrossRef]

36. Abourida, A.; Er-rouane, S.; Bahir, M.; da Silva, M.O.; Cheggour, A. Contribution des isotopes de l'environnement pour la compréhension du fonctionnement de l'aquifère Mio-Plioquaternaire du Haouz de Marrakech (Maroc). Estudios Geol. 2004, 60, 161-167. [CrossRef]

37. Karroum, M.; El Mandour, A.; Khattach, D.; Cassas, A.; Himi, H.; Rochdane, S.; Laftouhi, N.; Khalil, N. Fonctionnement hydrogeologique du bassin de la Bahira (Maroc central): Apport de l'analyse des donneesgeologiques et grav- imetriques. Can. J. Earth Sci. 2014, 51, 517-526. [CrossRef]

38. Tagma, T. Ressources en eau souterraine de l'aquifère du souss-massa: Étude de la qualité et de la vulnérabilité. PhD. Thesis, University Ibnou Zohr Faculty of Sciences of Agadir, Agadir, Morocco, 2011; 120p.

39. Edmunds, W.M. Renewable and non-renewable groundwater in semi-arid and arid regions. Devel. Water Sci. 2003, 50, 265-280.

40. Elmeknassi, M.; El Mandour, A.; Elgettafi, M.; Himi, M.; Tijani, R.; El Khantouri, F.A.; Casas, A. A GIS-based approach for geospatial modeling of groundwater vulnerability and pollution risk mapping in Bou-Areg and Gareb aquifers, northeastern Morocco. Environ. Sci. Pollut. Res. 2021, 28, 51612-51631. [CrossRef]

41. Vengosh, A. Salinization and saline environments. In Environmental Geochemistry; Sherwood Lollar, B., Ed.; Elsevier Science: Amsterdam, The Netherlands, 2003; pp. 333-365.

42. Aquilina, L.; Ladouche, B.; Doerfliger, N.; Seidel, J.L.; Bakalowicz, M.; Dupuy, C.; LeStrat, P. Origin, evolutionand residence time of saline thermal fluids (Balaruc springs, southern France): Implications for fluid transfer across thecontinental shelf. Chem. Geol. 2002, 192, 1-21. [CrossRef]

43. Wang, Y.; Guo, Q. Strontium isotope characterization and major iongeochemistry of karst water flow, Shentou, northern China. J. Hydrol. 2006, 328, 592-603. [CrossRef]

44. Bouchaou, L.; Chauve, P.; Mania, J.; Murdry, J.; Michelot, J.L. Apports des traçages artificiel et naturel à la connaissance des circulations et des zones de recharge en région semi-aride: Cas de l'Atlas de Béni-Mellal (Maroc). Rev. Des Sci. De L'eau 1995, 8, 43-55. [CrossRef]

45. Mahlknecht, J.; Garfias, J.; Aravena, R.; Tesch, R. Geochemical and isotopic investigations on groundwater residence time and flow in the Independence Basin, Mexico. J. Hydrol. 2005, 324, 283-300. [CrossRef]

46. Ladouche, B.; Luc, A.; Dor fliger, N. Chemical and isotopic investigation ofrainwater in Southern France (1996-2002): Potential use as input signal forkarst functioning investigation. J. Hydrol. 2009, 367, 150-164. [CrossRef] 
47. Bouchaou, L.; Tagma, T.; Boutaleb, S.; Hssaisoune, M.; El Morjani, Z. Climate change and its impacts on ground water resources in Morocco: The case of the Souss-Massa basin. In Climate Change Effects on Groundwater Resources: A Global Synthesis of Findings and Recommendations; International Association of Hydrogeologists: Reading, UK, 2012; Volume 27, pp. 129-144.

48. Mastrocicco, M.; Vignoli, G.; Colombani, N.; Zeid, N.A. Surface electrical resistivity tomography and hydrogeological characterization to constrain groundwater flow modeling in an agricultural field site near Ferrara (Italy). Environ. Earth Sci. 2010, 61, 311-322. [CrossRef]

49. Tazioli, A.; Conversini, P.; Peccerillo, A. Hydrogeological and geochemical characterization of the Rock of Orvieto. Environ. Earth Sci. 2012, 66, 55-65. [CrossRef]

50. Giang, N.V.; Thanh, L.N.; Hiep, V.Q.; Hida, N. Hydrological and hydrogeological characterization of groundwater and river water in the North Hanoi industrial area. Vietnam. Environ. Earth Sci. 2014, 71, 4915-4924. [CrossRef]

51. Chouikri, I.; El Mandour, A.; Jaffal, M.; Baudron, P.; García-Aróstegui, J.; Manar, A.; Casas, A. Gravimetry contributions to the study of the complex western Haouz aquifer (Morocco): Structural and hydrogeological implications. J. Afr. Earth Sci. 2015, 115, 234-245. [CrossRef]

52. Bouatmani, R.; Alami, A.; Medina, F. Subsidence, évolution thermique et maturation des hydrocarbures dans le bassin d'Essaouira (Maroc): Apport de la modélisation. Bull. De L'institut Sci. Rabat Sect. Sci. De La Terre 2007, 29, 15-36.

53. Sinan, M. Méthodologie D'identification, D'évaluation et de Protection des Ressources en eau des Aquifères Régionaux par la Combinaison des SIG, de la Géophysique et de la Géostatistique: Application à L'aquifère du Haouz de Marrakech (Maroc). Ph.D. Thesis, Mohammed V University, Mohammadi School of Engineering, Rabat, Morocco, 2000; 353p.

54. Abourida, A. The Hydrogeological Approach of the Haouz Aquifer (Morocco) by Teledetection, Isotopy, GIS and Modelling. Ph.D. Thesis, Cadi Ayyad, Marrakech, Morocco, 2007.

55. Soulaimani, A. L'evolution Structurale des Affleurementspaleozoïquesdu Haouz de Marrakech (Guemassa-Nfis)—Maroc. These3 eme Cycle; Cadi Ayyad University: Marrakech, Morocco, 1991; p. 180.

56. El Mandour, A.; Khattach, D.; Boughriba, M.; Mania, J.; Aboufirrassi, M.; El Hebil, A. Comportement Bicouche du Reservoir Fissure du Massif des Jebilet (Meseta occidentale, Maroc). In Sciences et techniques de l'environnement. Mémoire hors-série; Université de Franche Comté: Besançon, France, 2001; pp. 137-140.

57. Boukhari, K. La plaine de Mejjate et sa bordure occidentale: Actualisation desconnaissances hydrogéologiques et vision prospective de la mobilisation desressources en eau. Ph.D. Thesis, Université Cadi Ayyad, Marrakech, Morocco, 2008; 159p.

58. Ambroggi, R.; Thuille, G. Les Plaines et les Plateaux des Domaines Marginal de l'Atlas, Haouz de Marrakech. Hydrogeologie du Maroc; Notes et memoires N120; Service Geologique: Rabat, Morocco, 1987; p. 50.

59. Hydraulic Basin of Tensift Agency ABHT; Division des Ressourceseneau (DRE): Morocco, 2012.

60. Hydraulic Basin of Tensift Agency ABHT. Etude de la Structure des Aquifères en Amont de Ain Abainouparméthode Electrique (Province de Chichaoua); GéoAtlas: Hendaye, France, 2009.

61. Hydraulic Basin of Tensift Agency ABHT. Etude par Prospection Electrique de la Plaine d'Oulad Bou Sbaa, Province de Chichaoua; MEDITECIN: Mostná, Slovakia, 2010.

62. Boumaggard, E.H.; Jourani, E.; Mchichi, M.; Griboulard, R.; Hamoumi, N.; Daoudi, L. Analyse du réseau de thalwegs comme marqueur structural: Application au gisement phosphaté des Oulad Bou Sbaa (Haut Atlas occidental, Maroc). Ann. Soc. Géol. Du Nord 2001, T8, 173-179.

63. Enanaâ, N. Etude Hydroclimatologique et Hydrogéologique des Aquifères de Laplaine de Mejjate et sa Bordure Occidentale, Simulation Numérique Des Ecoulementssouterrains de la Plaine de Mejjate (Maroc). Ph.D. Thesis, Université de Tunis II, Tunis, Tunisia, 2000; 205p.

64. Clark, I.; Fritz, P. Environmental Isotopes in Hydrogeology; CRC Press: Boca Raton, FL, USA, 1997.

65. Chouikri, I. Contribution à l'étude des Eaux Souterraines de la Plaine du Haouz Occidental et la Plaine de Mejjate: Approche Hydrogéologique, Géophysique et Géochimique. Maroc occidental. Ph.D. Thesis, Faculté des Sciences Semlalia-Marrakech, Marrakesh, Morocco, 2017.

66. Hydraulic Basin of Tensift Agency (ABHT). Etude de Révision du plan Directeur D'aménagement Intégré des Ressources en Eau Des Bassins du Tensift, Ksob et Igouzoulen; Hydraulic Basin of Tensift Agency (ABHT): Tensift, Morocco, 2014.

67. Craig, H. Isotopic variation in meteoric waters. Science 1961, 133, 1702-1703. [CrossRef] [PubMed]

68. El Bouqdaoui, K.; Aachib, M.; Blaghen, M.; Kholtei, S. Modélisation de la pollution par les nitrates de la nappe de Berrechid, au Maroc. Afr. Sci. 2009, 5, 99-113. [CrossRef]

69. Lyakhloufi, S. Vulnerability and Pollution Risk of the Water Table of the Haouz. Ph.D. Thesis, Cadi Ayyad University, Marrakech, Morocco, 2001.

70. Chaib, W.; Bouchahm, N.; Harrat, N.; Zahi, F.; Bougherira, N.; Djabri, L. Caractérisation hydrogéochimique des eaux géothermales de la nappe du continental intercalaire de la région de l'Oued Righ. J. Alg. Rég. Arid. 2013, 12, 55-64.

71. Fidelibus, M.D.; Tulipano, L. Mixing phenomena owing to sea water intrusion for the interpretation of chemical and isotopic data of discharge water in the apulian coastal carbonate aquifer (Southern Italy). In Proceedings of the 9th Salt Water Intrusion Meeting, Delft, The Netherlands, 12-16 May 1986; pp. 591-600.

72. Stigter, T.Y.; van Ooijen, S.P.J.; Post, V.E.A.; Appelo, C.A.J.; Dill, A.C. A hydrogeological and hydrochemical explanation of the groundwater composition under irrigated land in a Mediterranean environment, Algarve, Portugal. J. Hydrol. 1998, 208, 262-279. [CrossRef] 
73. Subyani, A. Hydrochemical identification and salinity problem of ground-water in Wadi Yalamlam basin, Western Saudi Arabia. J. Arid Environ. 2005, 60, 53-66. [CrossRef]

74. Cidu, R.; Biddau, R.; Fanfani, L. Impact of past mining activity on the quality of groundwater in SW Sardinia (Italy). J. Geochem. Explor. 2009, 100, 125-132. [CrossRef]

75. Gouaidia, L.; Nabil, D.; Noureddine, Z.; Fr, C. Origine de la mineralisation des eaux souterraines d 'un aquifere dans une zone semi-aride, cas de la nappe de la merdja, nord-est algerien. Int. J. Environ. Water 2017, 6, 104.

76. Alaya, M.B.; Saidi, S.; Zemni, T. Évaluation de l'aptitude des eaux souterraines profondes à la consommation et à l'irrigation dans les aquifères de la Djeffara (nord de Gabès, sud-est de la Tunisie). Environ. Earth Sci. 2014, 71, 3387-3421. [CrossRef]

77. Moukhchane, M. Contribution à l'étude des Réservoirs Profonds de la Bordure Nord de l'Atlas Entre Demnat et Imin'tanout (Maroc). Ph.D. Dissertation, Université de Besançon, Besançon, France, 1983.

78. Mester, T.; Szabo, G.; Balla, D. Évaluation des processus de purification des eaux souterraines peu profondes après la construction d'un réseau d'égouts municipal. Eau 2021, 13, 1946. [CrossRef]

79. Rochdane, S.; Reddy, D.V.; El Mandour, A. Hydrochemical and Isotopic Characterisation of Eastern Haouz Plain Groundwater, Morocco; Environmental Earth Sciences-Springer: Berlin/Heidelberg, Germany, 2014; ISSN 1866-6280. [CrossRef]

80. Epstein, S.; Mayeda, T. Variation de la teneur en O18 des eaux d'origine naturelle. Geochim. Cosmochim. Acta 1953, 4, 213-224. [CrossRef]

81. Ettayfi, N.; Bouchaoua, L.; Michelot, J.L. Contraintes géochimiques et isotopiques (oxygène, hydrogène, carbone, strontium) pour l'origine, la salinité et le temps de séjour des eaux souterraines d'un aquifère carbonaté dans les montagnes de l'Anti-Atlas occidental, Maroc. J. Hydrol. 2012, 438, 97-111. [CrossRef]

82. El Ghali, T.; Qurtobi, M.; Marah, H.; Raibi, F.; El Mansouri, B. Caractérisation chimique et isotopique des eaux pluviales du bassin de Berrechid, Maroc. J. Water Sci. Environ. Technol. 2018, 3, 335-341.

83. Giraud, G. La Théorie Des Jeux; Collection; Champs Université: Paris, France, 2000.

84. Kazakis, N.; Matiatos, I.; Ntona, M.M.; Bannenberg, M.; Kalaitzidou, K.; Kaprara, E.; Mitrakas, M.; Ioannidou, A.; Vargemezis, G.; Voudouris, K. Origin, implications and management strategies for nitrate pollution in surface and ground waters of Anthemountas basin based on a $815 \mathrm{~N}-\mathrm{NO} 3-$ and $818 \mathrm{O}-\mathrm{NO} 3$ - isotope approach. Sci. Total Environ. 2020, 724, 138211. [CrossRef]

85. Mook, W.G. Environmental isotopes in the hydrological cycle, Principles and applications. In Technical Documents in Hydrology, N 39; Unesco: Paris, France, 2001; Volume 5. 